Utah State University

DigitalCommons@USU

T.W. "Doc" Daniel Experimental Forest

Quinney Natural Resources Research Library,

S.J. and Jessie E.

2020

\title{
Aspen Soils Retain More Dissolved Organic Carbon Than Conifer Soils in a Sorption Experiment
}

Antra Boca

Astrid R. Jacobson

Helga Van Miegroet

Follow this and additional works at: https://digitalcommons.usu.edu/docdan

Part of the Life Sciences Commons, and the Physical Sciences and Mathematics Commons

\section{Recommended Citation}

Boča A, Jacobson AR and Van Miegroet H (2020) Aspen Soils Retain More Dissolved Organic Carbon Than Conifer Soils in a Sorption Experiment. Front. For. Glob. Change 3:594473. doi: 10.3389/

ffgc. 2020.594473

This Article is brought to you for free and open access by the Quinney Natural Resources Research Library, S.J. and Jessie E. at DigitalCommons@USU. It has been accepted for inclusion in T.W. "Doc" Daniel Experimental Forest by an authorized administrator of DigitalCommons@USU.

For more information, please contact

digitalcommons@usu.edu.

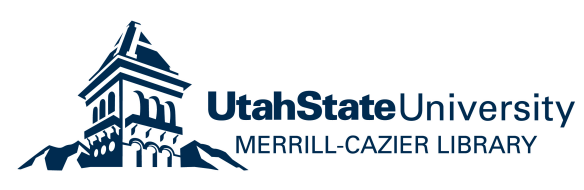




\section{OPEN ACCESS}

Edited by:

Jérôme Laganičre

Canadian Forest Service, Canada

Reviewed by:

Sylvie Quideau,

University of Alberta, Canada

Lars Vesterdal,

University of Copenhagen, Denmark

*Correspondence:

Antra Boča

antraboca@gmail.com

Specialty section:

This article was submitted to

Forest Soils,

a section of the journal

Frontiers in Forests and Global

Change

Received: 13 August 2020

Accepted: 29 October 2020

Published: 03 December 2020

Citation:

Boča A, Jacobson AR and

Van Miegroet H (2020) Aspen Soils Retain More Dissolved Organic Carbon Than Conifer Soils in a

Sorption Experiment.

Front. For. Glob. Change 3:594473.

doi: 10.3389/ffgc.2020.594473

\section{Aspen Soils Retain More Dissolved Organic Carbon Than Conifer Soils in a Sorption Experiment}

\author{
Antra Boča ${ }^{1,2 *}$, Astrid R. Jacobson ${ }^{3}$ and Helga Van Miegroet ${ }^{2}$ \\ ${ }^{1}$ Faculty of Environment and Civil Engineering, Latvia University of Life Sciences and Technologies, Jelgava, Latvia, \\ ${ }^{2}$ Department of Wildland Resources, Utah State University, Logan, UT, United States, ${ }^{3}$ Department of Plants, Soils \\ and Climate, Utah State University, Logan, UT, United States
}

The effect tree species have on soil organic carbon (SOC) has been hotly debated but, so far, few clear patterns have emerged. One example of a differing tree species effect on SOC are aspen forests in North America, which have been found to have more stable SOC than adjacent conifer forest stands. An important source for the formation of stable organo-mineral complexes in soil is dissolved organic carbon (DOC). DOC concentrations in mineral soil are often higher under the thick O-horizons of conifer forests than under aspen forests, but this does not correspond to more stable mineral SOC. This suggests that, instead of DOC concentration, DOC quality could be driving the observed differences in SOC. Therefore, we quantified the retention of contrasting forest detritus DOC in soils. Using a batch sorption experiment approach, we compared the retention of detritus leachates from four sources - aspen leaves (AL), aspen roots $(A R)$, conifer (subalpine fir) needles $(C N)$, and conifer (subalpine fir) roots $(C R)$ - on soils sampled under aspen and conifer (subalpine fir and Douglas fir) overstories. The calculated sorption isotherms showed a higher retention of AL DOC than AR DOC, as indicated by all four sorption parameters $-k$ and $n$ (curve-fitting parameters), null point concentration (NPC; net sorption = net desorption), and endpoint (EP, retention at the highest initial DOC concentration). Leachates from $\mathrm{CN}$ and $\mathrm{CR}$ showed very similar retention behavior, and between the two species the retention of root leachates was more similar than the retention of foliage leachates. Soils sampled from aspen forests showed higher affinity for new DOC than conifer soils [higher sorption rate (n), lower NPC, and higher EP] regardless of the DOC source. The findings suggest that the higher DOC sorption on aspen soils might be a major driver for more stable SOC under aspen stands in North America.

Keywords: aspen, dissolved organic carbon, foliage, roots, sorption, tree species

\section{INTRODUCTION}

As forest soils store as much carbon as aboveground biomass (Pan et al., 2011), information on tree species' effects on soil organic carbon (SOC) storage is of interest to ecologists, ecosystem modelers, and forest managers. Most synthesis studies on this topic have not found globally consistent patterns (Vesterdal et al., 2013; Boča et al., 2014; Lin et al., 2017), but some species or functional groups stand out in terms of SOC storage and stabilization. 
In a literature review, Laganière et al. (2017) reported that, in North America, SOC under quaking aspen (Populus tremuloides Michx.) is consistently more stable than under adjacent conifer stands. This is an important finding considering that quaking aspen is the most widely distributed tree species in North America (Little, 1971), and its current decline (Rogers, 2002; Di Orio et al., 2005) is often accompanied by conifer encroachment (Potter, 1998). While no consistent difference in SOC pools was detected by Laganière et al. (2017), in several areas in the state of Utah, United States, higher SOC stability was also associated with higher total SOC pools compared to nearby conifer stands (Woldeselassie et al., 2012; Boča and Van Miegroet, 2017). An analysis of $C$ fluxes in these ecosystems (higher litterfall under aspen, higher DOC concentrations under conifers, higher fine root biomass under conifers, similar root turnover under both overstories), however, could not explain the differences in SOC pools under both overstory types (Boča and Van Miegroet, 2017). This leaves two mechanisms as potential drivers: (i) difference in dissolved organic matter (DOM) quality and sorption, and/or (ii) difference in root exudation. In this region, as in most of the Intermountain Western US, the majority $(>75 \%)$ of the precipitation falls as snow. Spring snowmelt creates the largest soil water fluxes that affect the whole soil profile (fall rains mostly affect only topsoil) (LaMalfa and Ryle, 2008). This makes spring snowmelt water fluxes a likely pathway for $\mathrm{C}$ redistribution in soil, as soil macrofauna have not been observed in these areas (Ayres et al., 2009; Boča and Van Miegroet, 2017). We are not aware of a study that has compared root exudation under aspen and conifer trees. Higher specific root length of aspen compared to conifers (e.g., Steele et al., 1997; Bauhus and Messier, 1999) could, however, suggest more dynamic belowground processes under aspen. In this study, we examined the first mechanism: DOM quality and sorption.

In its dissolved form, organic matter can be transported through the soil profile and sorbed to mineral surfaces or incorporated into microbial biomass attached to these surfaces, thus participating in the formation of stable mineral-bound organic matter (Qualls, 2000; Kalbitz et al., 2005; Kalbitz and Kaiser, 2008). Factors affecting sorption are: (i) $\mathrm{Fe}$ and $\mathrm{Al}$ oxyhydroxide concentrations in soil (e.g., Moore et al., 1992; Lilienfein et al., 2004; Heckman et al., 2011); (ii) native SOC concentration, which affects the potential of soils to retain more C (Hassink, 1997; Six et al., 2002; Stewart et al., 2007); and (iii) the quantity and quality of dissolved organic carbon (DOC). Higher concentrations of DOC are known to result in higher total retention of $\mathrm{C}$ in laboratory sorption experiments, but DOC fluxes in the field do not correlate with SOC pools (as reviewed by Michalzik et al., 2001). Field measurements in Utah revealed higher DOC concentrations in soils under conifers (Boča and Van Miegroet, 2017). Considering that the examined plots were less than $50 \mathrm{~m}$ apart, and had similar soil characteristics (Van Miegroet et al., 2005; Olsen and Van Miegroet, 2010; Boča and Van Miegroet, 2017), the higher DOC under conifers should have resulted in higher $\mathrm{C}$ concentrations and higher mineral-associated SOC. Yet the opposite pattern was observed (Román Dobarco and Van Miegroet, 2014; Boča and Van Miegroet, 2017). This again suggests that other factors, such as DOC quality, are potentially more important drivers for sorption in this case.

The litter of quaking aspen is considered more labile than conifer litter due to differences in nutrient and lignin concentrations (Moore et al., 2006). In a litter decomposition study, Prescott et al. (2000) also suggested leaching losses as a major reason for faster aspen vs. conifer litter degradation. In the first year of decomposition, the mass loss of $35 \%$ from aspen litter (Prescott et al., 2000) was similar to the $32 \%$ leachable content from aspen litter observed by Taylor et al. (1989). DOM quality has been proposed as a major factor affecting organic matter sorption in soil with hydrophobic and more aromatic compounds being preferentially sorbed to mineral surfaces compared to more labile polysaccharide-derived hydrophilic DOM (Kaiser and Guggenberger, 2000; Kalbitz et al., 2005). Recently, Cotrufo et al. (2015) showed that SOC can be formed with high efficiency through microbial processing of DOM produced during the early stages of litter decomposition (labile non-structural compounds).

Root detritus is considerably less examined as a source of DOM, prohibiting researchers from calculating estimates of root DOC contribution to SOC (Kalbitz and Kaiser, 2008). Based on a soil column experiment, Uselman et al. (2007) suggested that root DOC could contribute to the accumulation of SOC, and later reported that fine root DOM was less labile than foliage DOM (Uselman et al., 2012). Hansson et al. (2010) reported no differences in aromaticity and sorption rates between root and needle DOM, but did find lower DOC production rates from roots. Both studies examined root and foliage DOM from coniferous species. We are not aware of any published data on root DOM quality from contrasting tree species. Finér et al. (1997) reported faster aspen root decomposition compared to adjacent conifers, but, as no data on root quality were recorded, it is unclear whether faster decomposition reflects differences in root DOM quality. Overall, the sorption of root DOM is a knowledge gap that needs to be filled.

The objective of this study was to investigate the retention and release (sorption and desorption) by forest soils of foliage- and root-derived DOC from two contrasting tree species - quaking aspen and subalpine fir [Abies lasiocarpa (Hook.) Nutt.] - in the montane regions of Utah in the western US. The proximity of the aspen and conifer forest stands in Utah's mountains, and their contrasting litter quality, make them ideal study systems to answer questions regarding the effects of substrate quality on DOC sorption. We used a batch sorption approach to quantify DOC retention based on: (i) the source and quality of leachate derived from aspen and fir, and (ii) soil properties at different sites and soil depths. We hypothesized that: (i) aspen foliage DOC will be more labile in its chemical composition than root DOC and fir needle DOC, and thus will be more effectively retained in the soil; (ii) native DOC will sorb better on native soil; (iii) topsoils will experience lower sorption due to higher initial SOC concentrations than subsoils; and (iv) soils with higher $\mathrm{Fe}$ and $\mathrm{Al}$ oxyhydroxide concentrations will experience higher sorption. 


\section{MATERIALS AND METHODS}

\section{Soil Sampling and Analysis}

Soils for the experiment were collected from adjacent aspen and conifer forest stands at T. W. Daniels Experimental Forest (TWDEF) in northern Utah and at Cedar Mountain (CM, specifically plot CM17) in southern Utah. A detailed description of the sampling sites and the sampling procedure is provided in Boča and Van Miegroet (2017). In brief, TWDEF is located at $2600 \mathrm{~m}$ elevation with an average annual temperature of $3.1^{\circ} \mathrm{C}$ and mean annual precipitation of $1031 \mathrm{~mm}$, with about $70 \%$ accumulating as snow (NRCS ${ }^{1}$; USU Doc Daniel SNOTEL station). Cedar Mountain is a high-elevation plateau (1800$3200 \mathrm{~m}$ ) with an average annual precipitation of $823 \mathrm{~mm}$ and a mean annual temperature of $4.7^{\circ} \mathrm{C}$ [NRCS (see footnote 1); Kolob and Webster flat SNOTEL stations). Forests at both sites most likely originated from natural regeneration about a century ago (Wadleigh and Jenkins, 1996; DeRose and Long, 2007). Soils at both sites have been classified as Mollisols and Alfisols under aspen stands and as Alfisols under conifer stands, according to USDA soil taxonomy (McNab and Avers, 1994; Van Miegroet et al., 2005; Olsen and Van Miegroet, 2010).

The CM soils had two to three times higher total $\mathrm{Fe}$ and $\mathrm{Al}$ oxyhydroxide and SOC concentrations than those at TWDEF (Table 1; Boča and Van Miegroet, 2017). As oxyhydroxides affect sorption behavior (e.g., Heckman et al., 2011; Kramer et al., 2012), we considered site as a factor in further analyses. The soils were collected from the top $10 \mathrm{~cm}$ (topsoil) and 40-50 cm (subsoil) of the soil profile to capture differences in native SOC concentration within a given overstory type. The lower sampling depths correspond to the $\mathrm{ABt}$ and BAt horizons under aspen and Bt horizons under conifers.

Soil texture was determined by particle size analysis with the hydrometer method at Utah State University's Analytical Lab. pH was measured by mixing $10 \mathrm{~mL}$ soil with $10 \mathrm{~mL}$ water on the ATI Orion 950 Ross FASTQC Titrator. Soils were extracted in triplicate with sodium pyrophosphate $(\mathrm{NaPP})$, acid ammonium oxalate (AAO), and citrate-dithionite (CD) to estimate $\mathrm{Fe}$ and $\mathrm{Al}$ that were organically bound, or present in short range ordered (non-crystalline) and crystalline hydrous mineral phases (Sparks et al., 1996). The extracts were analyzed with an Atomic Absorption Spectrometer (Varian AA240 flame atomization, Australia). Concentrations of non-crystalline $\mathrm{Fe}$ and $\mathrm{Al}$ oxyhydroxides were calculated by subtracting $\mathrm{NaPP}$ values from AAO values, and concentration of crystalline $\mathrm{Fe}$ oxides was calculated by subtracting AAO from CD. Clay mineralogy was determined with an X-Ray diffraction spectrometer (Panalytical X'Pert Pro with monochromatic $\mathrm{Cu} \mathrm{K}$-alpha radiation). The soil was ground to $<250 \mu \mathrm{m}$ and analyzed for total organic carbon and inorganic C with Skalar Primacs ${ }^{S L C}$ Analyzer (Skalar, Inc., Breda, Netherlands).

\footnotetext{
${ }^{1}$ Natural Resources Conservation Service [NRCS]. Snow Telemetry (SNOTEL) Precipitation and Air Temperature Data for Webster Flat, Kolog, Tony Grove Lake (Utah) (1981-2010). Available online at: http://www.wcc.nrcs.usda.gov/snow/ (accessed November 25, 2014).
}

\section{Leachate Preparation and Analyses}

The plant material used in the experiment was collected at TWDEF and CM at the end of the 2015 growing season, and consisted of senesced aspen leaves, subalpine fir needles, and fine roots ( $<2 \mathrm{~mm}$ diameter) obtained from soil cores in both forest types at both sampling sites. The needles used were older, and collected from the Oi layer of the O-horizon. They were mixed with freshly senesced needles based on calculations of annual litterfall additions to the O-horizon. This was done to ensure that we are comparing similar material (i.e., Oi layer) for aspen and fir. We used a mix of older and fresh fir needles because, in contrast to aspen stands, most of the DOC under conifers originates from an O-horizon, which is mostly dominated by older foliage material in various stages of decomposition (Fröberg et al., 2003). The material was ground with a Wiley mill (20 mesh; Thomas Scientific, NJ, United States), analyzed for C with Skalar Primacs ${ }^{S L C}$ Analyzer (Skalar, Inc., Breda, Netherlands), and for total nitrogen with PDZ Europa ANCA GSL IRMS elemental analyzer (Sercon Ltd., Cheshire, United Kingdom).

DOC stock solutions were obtained following a method developed prior to the experiment. In brief, $20 \mathrm{~g}$ of ground foliage or root material were saturated with ultrapure water and subjected to two freeze-thaw cycles for a week to facilitate the release of DOC from substrates. Freezing and thawing are common processes in the field sites during fall when air temperatures drop below $0^{\circ} \mathrm{C}$ during night, and rise above freezing during the day $^{2}$ (NRCS SNOTEL - Kolob station). The thawing temperature was set at $5^{\circ} \mathrm{C}$ to reduce microbial decomposition of the material. After thawing the material a second time, the substrates were leached with $2 \mathrm{~L}$ of a 0.08 millimolar $\mathrm{KCl}$ solution, which corresponded to an electrical conductivity (EC) of around $10 \mu \mathrm{S} \mathrm{cm}{ }^{-1}$, similar to the EC detected in snow sampled from the TWDEF site during spring 2014 and 2015 (Boča, unpublished data). The leachates were created by vacuum-filtering a litter-water slurry through a glass fiber filter (Sterlitech $0.4 \mu \mathrm{m}$ ).

The stock solution of each leachate was analyzed for DOC immediately after the leaching, so that four working concentrations of around 10,20, 40, and $80 \mathrm{mg} \mathrm{L}^{-1}$ could be prepared on the same day as the stock solution. The DOC concentrations used were within the range of DOC concentrations observed in soil pore water at TWDEF (Boča and Van Miegroet, 2017). The working solutions were adjusted with $\mathrm{KCl}$ to have a constant EC of around $150 \mu \mathrm{S} \mathrm{cm} \mathrm{cm}^{-1}$ (1 millimolar $\mathrm{KCl}$ ), similar to the highest values detected in soil pore water at TWDEF, and analyzed for DOC with the wet oxidation persulfate UV method using a Phoenix 8000 Carbon Analyzer (Tekmar-Dohrmann, OH, United States). The $\mathrm{pH}$ of leachates was measured in stock solutions, which had DOC concentrations of around $150 \mathrm{mg} \mathrm{L}^{-1}$. The only exception was the stock solution derived from aspen leaves, which had DOC concentrations close to $1000 \mathrm{mg} \mathrm{L}^{-1}$, and, hence, had to be diluted prior to $\mathrm{pH}$ measurements.

\footnotetext{
${ }^{2}$ http://twdef.usu.edu/TWDEF/
} 
TABLE 1 | Selected soil properties from TWDEF and CM study sites.

\begin{tabular}{|c|c|c|c|c|c|c|c|c|c|}
\hline \multirow[t]{2}{*}{ Site/horizon } & \multirow[t]{2}{*}{ Texture } & \multirow[t]{2}{*}{$\mathrm{pH}\left(\mathrm{H}_{2} \mathrm{O}\right)$} & \multicolumn{3}{|c|}{$\mathrm{Fe}\left(\mathrm{mg} \mathrm{g}^{-1}\right)$} & \multicolumn{2}{|c|}{$\mathrm{Al}\left(\mathrm{mg} \mathrm{g}^{-1}\right)$} & \multirow[t]{2}{*}{ Clay minerals } & \multirow[t]{2}{*}{$\mathrm{C} \%$} \\
\hline & & & Org & Non-cryst & Cryst & Org & Non-cryst & & \\
\hline TWDEF A 0-10 & $\begin{array}{l}\text { Loam }(23 \% \\
\text { clay) }\end{array}$ & 6.1 & $0.79 \pm 0.08$ & $2.21 \pm 0.6$ & $3.39 \pm 0.46$ & $1.83 \pm 0.24$ & $0.55 \pm 0.05$ & $\begin{array}{l}\text { Illite, Kaolinite, } \\
\text { Muscovite, } \\
\text { Vermiculite }\end{array}$ & 3.11 \\
\hline TWDEF A 40-50 & $\begin{array}{l}\text { Clay loam } \\
\text { (28\% clay) }\end{array}$ & 6.1 & $0.68 \pm 0.06$ & $2.22 \pm 0.68$ & $4.07 \pm 0.88$ & $0.91 \pm 0.03$ & $0.99 \pm 0.31$ & & 1.02 \\
\hline TWDEF C 0-10 & $\begin{array}{l}\text { Loam }(24 \% \\
\text { clay) }\end{array}$ & 5.5 & $0.87 \pm 0.4$ & $1.22 \pm 0.49$ & $2.88 \pm 0.42$ & $1.33 \pm 0.46$ & $0.64 \pm 0.03$ & $\begin{array}{l}\text { Illite, Dickite, } \\
\text { Kaolinite, } \\
\text { Vermiculite }\end{array}$ & 2.42 \\
\hline TWDEF C 40-50 & $\begin{array}{l}\text { Clay loam } \\
\text { ( } 29 \% \text { clay) }\end{array}$ & 5.4 & $0.81 \pm 0.29$ & $1.27 \pm 0.39$ & $3.29 \pm 0.5$ & $1.09 \pm 0.13$ & $0.71 \pm 0.12$ & & 0.61 \\
\hline CM A 0-10 & $\begin{array}{l}\text { Loam }(21 \% \\
\text { clay) }\end{array}$ & 5.4 & $1.09 \pm 0.28$ & $9.18 \pm 0.43$ & $4.74 \pm 0.6$ & $1.22 \pm 0.17$ & $2.95 \pm 0.42$ & $\begin{array}{l}\text { Illite, Kaolinite, } \\
\text { Vermiculite, } \\
\text { Mica }^{a}\end{array}$ & 5.02 \\
\hline CM A 40-50 & $\begin{array}{l}\text { Loam }(25 \% \\
\text { clay) }\end{array}$ & 6.4 & $2.82 \pm 0.25$ & $8.25 \pm 0.34$ & $5.7 \pm 1.07$ & $2.15 \pm 0.05$ & $3.04 \pm 0.12$ & & 3.13 \\
\hline CM C 0-10 & $\begin{array}{l}\text { Loam }(23 \% \\
\text { clay) }\end{array}$ & 5.3 & $1.53 \pm 0.08$ & $10.02 \pm 1.53$ & $4.68 \pm 1.81$ & $2.09 \pm 0.05$ & $2.79 \pm 0.29$ & $\begin{array}{l}\text { Illite, Kaolinite, } \\
\text { Vermiculite }\end{array}$ & 4.72 \\
\hline CM C 40-50 & $\begin{array}{l}\text { Loam (18\% } \\
\text { clay) }\end{array}$ & 5.9 & $3.4 \pm 0.05$ & $7.54 \pm 0.9$ & $5.64 \pm 1.61$ & $2.67 \pm 0.04$ & $2.54 \pm 0.07$ & & 2.57 \\
\hline
\end{tabular}

${ }^{a}$ Due to the high concentration of non-crystalline Fe and Al oxides, the clay mineralogy could not be fully described with XRD in CM soils.

\section{Experimental Setup}

The experimental setup is depicted in Figure 1. In brief, the experiment had four leachate treatments - aspen leaves (AL), aspen roots (AR), conifer (subalpine fir) needles $(\mathrm{CN})$, and conifer (subalpine fir) roots (CR) - and eight soil types - TWDEF aspen (TA), TWDEF conifer (TC), CM17 aspen (CMA), CM17 conifer (CMC), from $0-10$ and $40-50 \mathrm{~cm}$ soil depths. The conifer stands, from which soils were sampled, were dominated by subalpine fir at TWDEF, and by Douglas fir (Pseudotsuga menziesii Mirb.) at CM.

In this experiment, the two depths represent differences in initial $\mathrm{C}$ concentration under the same overstory, which is thought to affect soil C saturation/deficiency. Considering that the forests investigated had not been managed for timber production for at least a century, we assumed that SOC levels were at steady-state. Following the same assumptions as studies that developed the C saturation capacity concept (Hassink, 1997; Six et al., 2002; Stewart et al., 2007), we assumed that the upper soil was closer to SOC saturation and thus had lower $\mathrm{C}$ retention capacity while the soil at greater depth had a higher $\mathrm{C}$ deficiency.

The study was a full factorial experiment $(32$ combinations of leachate and soil), such that every soil was mixed with every concentration of every leachate (1:10 soil to solution $\mathrm{w} / \mathrm{v}$ ratio), and a pure $\mathrm{KCl}$ solution (DI water with no DOC) with an EC of $150 \mu \mathrm{S} \mathrm{cm} \mathrm{cm}^{-1}$ was included to measure the desorption of native SOC (Figure 1). The experiment was done in triplicate for

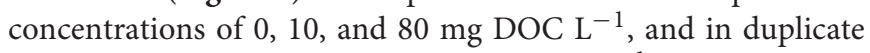

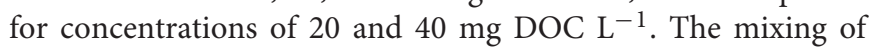
soil and solution was done in glass jars with septa caps to allow for measurements of $\mathrm{CO}_{2}$ evolution from heterotrophic activity after shaking. The jars were shaken in the dark on an orbital shaker for $24 \mathrm{~h}(100 \mathrm{rpm})$ at room temperature. Due to the

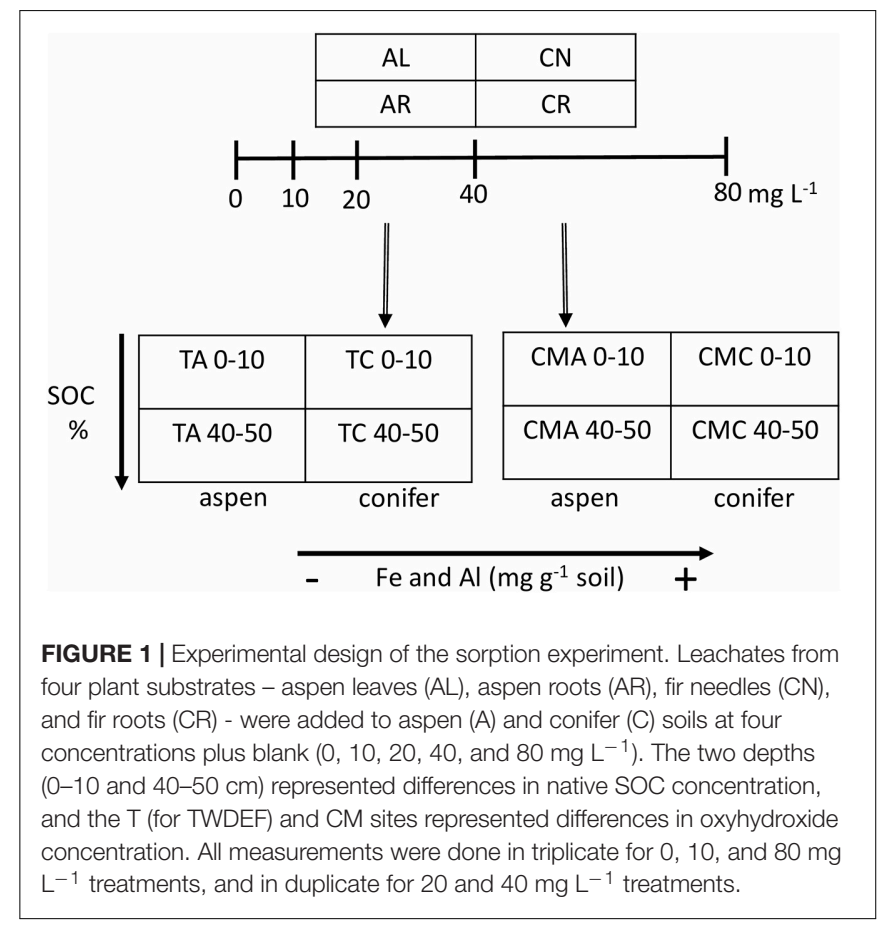

sample size, the shaking (equilibration) had to be split in 2 days. The first round of samples were prepared on the same day as the leachates themselves, and the second round was prepared on the next day. After shaking, $\mathrm{CO}_{2}$ within the jars was measured by inserting needle extensions through the septa and analyzing the gas with a LICOR-8100 gas analyzer (LI-COR, Inc., NE, United States). Afterward, all samples were filtered through a 
$0.4 \mu \mathrm{m}$ glass fiber filter (Sterlitech) and analyzed for DOC as described in subsection "Leachate Preparation and Analyses."

\section{Fluorescence Analysis}

Leachate (pre-sorption) and post-sorption solution quality was assessed with fluorescence and absorbance spectroscopy using an Aqualog fluorometer (Horiba Jobin Yvon, Japan). Fluorescence excitation wavelengths ranged from 248 to $800 \mathrm{~nm}$, at an increment of $6 \mathrm{~nm}$, while the emission range was $249-828 \mathrm{~nm}$ at an increment of approximately $4.5 \mathrm{~nm}$. As the Aqualog measures fluorescence and absorbance simultaneously, so absorbance was measured at the same wavelengths as excitation. Each sample was diluted to not exceed $0.3 \mathrm{~cm}^{-1}$ absorbance at $254 \mathrm{~nm}$ (Miller et al., 2010) to minimize inner-filter effects; this corresponded to approximately 7-10 mg DOC $\mathrm{L}^{-1}$. The samples were measured at their natural $\mathrm{pH}$ as we were interested in the characterization of the natural DOM (see Cuss et al., 2014, for more information on $\mathrm{pH}$ effects on plant leachate fluorescence).

The fluorescence spectra were Raman normalized, corrected for the inner-filter effect, and blank-subtracted before calculating several spectroscopic indices and building a parallel factor analysis (PARAFAC) model (Murphy et al., 2013). All corrections and calculations were performed using the MATLAB (version R2017a) software. We calculated the humification index (HIX at ex $254 \mathrm{~nm}$, area of peak under em $435-480 \mathrm{~nm}$ divided by peak area under em 300-345 nm), the fluorescence index (FI em $470 \mathrm{~nm} / \mathrm{em} 520 \mathrm{~nm}$ at ex $370 \mathrm{~nm}$ ) (Gabor et al., 2014a), and, by using UV-Vis data, specific ultraviolet absorbance at $254 \mathrm{~nm}$ (SUVA = abs @ $254 \mathrm{~nm} \mathrm{~cm}{ }^{-1} \times 100 / \mathrm{DOC} \mathrm{mg} \mathrm{L}{ }^{-1}$; units $=\mathrm{L} \mathrm{mg} \mathrm{C}-1 \mathrm{~m}^{-1}$ ) as these have been utilized in other studies to characterize soil derived DOM (Gabor et al., 2014b; Strid et al., 2016). A higher value of the humification index (HIX) corresponds to lower hydrogen to carbon (H:C) ratios and indicates a greater degree of humification (Gabor et al., 2014a). The FI is used as an indicator of precursor material, with lower values indicative of DOM that is plant-dominated in origin, and higher values indicative of DOM that is predominately from microbial (originally algal) sources, with a difference in value of 0.1 considered to be significant (McKnight et al., 2001). SUVA has been used as a proxy for DOC aromaticity (Weishaar et al., 2003), hydrophobicity (Dilling and Kaiser, 2002), and microbial stability (Kalbitz et al., 2003).

To better characterize the quality of the DOM solutions, we analyzed the fluorescing compounds by building a PARAllel FACtor analysis (PARAFAC) model following the guidelines described by Murphy et al. (2013). PARAFAC uses all of the data contained in excitation-emission matrices (EEMs) to identify and quantify independent underlying spectral features, termed "components." A component represents a single fluorophore (compound that absorbs or re-emits light) or a group of highly related fluorophores (Fellman et al., 2010; Murphy et al., 2013; Aiken, 2014). A PARAFAC model was built using the drEEM toolbox (version 4.0). As input for the model we used all sorption and desorption (see subsection "Desorption") data, as well as data from pure leachates. After validation, all components were compared with information from a global model database using the OPENFluor plugin (Murphy et al., 2014) in OPENChrom ${ }^{\circledR}$
(Wenig and Odermatt, 2010; version Dalton) to estimate the chemical identity of each component. More detailed information regarding fluorescence measurements and model building is provided in Supplementary Material 1.

\section{Desorption}

At the end of the adsorption experiment, soils were dried in glass jars (same jars as used for the sorption process) for 7 days at $5^{\circ} \mathrm{C}$. Drying, a natural process in the examined soils, can potentially affect OM retention in soil (Borken and Matzner, 2009). We chose the drying temperature to reflect the natural soil temperature observed in the field (Scott Jones, unpublished data; raw data available at twdef.usu.edu). After drying, soils were extracted once with $40 \mathrm{~mL}$ of 1 millimolar $\mathrm{KCl}$ solution to determine desorption of the sorbed material. The desorption solutions underwent the same preparation procedure and measurements as the sorption solutions described in subsection "Experimental Setup" and "Fluorescence Analysis."

\section{Data Analyses}

Before fitting a sorption equation, we adjusted the data for $\mathrm{CO}_{2}-\mathrm{C}$ lost through mineralization. We calculated the $\mathrm{CO}_{2}$ concentration in the headspace using the ideal gas law, and by taking into account the $\mathrm{pH}$ of the solution we calculated the $\mathrm{CO}_{2}$ in the liquid phase. First, to correct for the "Birch effect" (Jarvis et al., 2007), and for the mineralization of native SOC, the $\mathrm{CO}_{2}$ measured for each sample was corrected by the $\mathrm{CO}_{2}$ measured for the same soil when only the pure $\mathrm{KCl}$ solution was added. The corrected values were then used to calculate sorption/desorption using the following equation:

$$
i D O C-s D O C-\mathrm{CO}_{2}-\mathrm{C}=r D O C
$$

where $i D O C$ is the initial DOC concentration added, $s D O C$ is the DOC concentration measured in the solution after $24 \mathrm{~h}$ of shaking, and $\mathrm{CO}_{2}-\mathrm{C}$ is the amount of $\mathrm{C}$ lost via mineralization. The resulting $r D O C$ is the DOC retained in soil or released from soil in the cases where no sorption occurred, which is why we further refer to DOC retention/release in the text. Finally, $r D O C$ was converted to $\mathrm{mg} \mathrm{C}$ retained/released per kg of soil.

To describe the sorption behavior of leachate DOC on soil, we fitted a non-linear function, loosely based on the Freundlich isotherm, using initial DOC concentrations and $r D O C$ values. Following suggestions by Lilienfein et al. (2004) and Vandenbruwane et al. (2007) we fit the non-linear curves by subtracting the native organic $\mathrm{C}$ released as DOC (from extraction with the $\mathrm{KCl}$ solution) from the original equation, meaning, the parameter " $a$ " was added, representing a non-zero intercept:

$$
r D O C=k \times C_{i}^{1 / n}-a
$$

In equation [2], $r D O C$ is the mass of DOC (mg) released/retained per mass of soil $(\mathrm{kg}), C_{i}$ is the DOC concentration added [initial DOC; as per Kothawala et al. (2008) who used it for the Langmuir equation], and " $a$ " is the $y$ intercept, which describes the native DOC released with the pure $\mathrm{KCl}$ solution (Vandenbruwane et al., 2007). Parameters $k$ 
and $n$ are curve-fitting parameters that together describe the shape of the curve. We used non-linear regression to estimate the parameters $k$ and $n$ using the function $n l s$ in the $\mathrm{R}$ package Stats (R Development Core Team, 2015, version 3.1.2).

We tested differences between leachate type and soil properties in regard to null point concentration (NPC; initial DOC concentration at which net sorption equals net desorption), endpoint (EP; $C$ sorbed at the highest concentration of DOC added), and parameters $k$ and $n$ with a factorial analysis of variance (ANOVA) testing for main effects and two-way interactions with $\alpha=0.05$. When significant, we performed post hoc Tukey HSD tests to determine differences between individual leachate types. The soil properties considered were: soil type, which represented differences in soils affected by aspen and conifer overstories; site, which was representative of differences in Fe and $\mathrm{Al}$ oxyhydroxide levels as well as site SOC concentrations (Boča and Van Miegroet, 2017); and depth, which represented differences relative to effective $\mathrm{C}$ saturation levels (topsoils closer to $\mathrm{C}$ saturation, and subsoils further away). Data were transformed where necessary to ensure equal variances and normal distribution of the residuals. We further tested the relationship between initial SOC concentration and the four retention response variables with a multivariate regression.

To compare PARAFAC results, we calculated the proportion that each PARAFAC component explained from total fluorescence. This approach allowed us to compare shifts in component dominance (solution quality) without having to consider the non-linear effect of concentration on fluorescence intensities. A high heterogeneity of variances in residuals among several factors (mostly leachate type and soil type) prohibited the use of an ANOVA, and, therefore, differences in components were analyzed for main effects only using the non-parametric Kruskal-Wallis test. If leachate type was found to have significant differences, we used the Wilcoxon signed rank test for pairwise comparisons with a Holm adjustment for the $p$-value to compare between the leachates. All statistical analyses were performed with the software $\mathrm{R}$ version 3.1.2 ( $\mathrm{R}$ Development Core Team, 2015). The values depicting results are reported as mean \pm standard deviation, unless noted otherwise.

\section{RESULTS}

\section{Soil Characterization}

As seen in Table 1, at each site, soils under both overstory types were fairly similar. All soils were loams with some soils at 40$50 \mathrm{~cm}$ depth being clay loams. The clay concentration was lowest in the CMC $40-50 \mathrm{~cm}$ soils at $18 \%$, and varied from 21 to $29 \%$ in the other soils. The clays at TWDEF were dominated by a mixture of 1:1 and 2:1 clays (kaolinite, illite, vermiculite with smaller peaks of dickite and muscovite). Similar XRD spectral peaks were also detected for CM soils, but due to the high oxyhydroxide concentration, which interfered with the XRD measurements, the clay mineralogy could not be fully described. At CM CD extractable "free" (sum of all three fractions) Fe and AAO extractable $\mathrm{Al}$ (sum of organically bound and non-crystalline fractions) oxyhydroxide concentrations were very similar among overstories and averaged around $16 \mathrm{mg} \mathrm{g}^{-1}$ for $\mathrm{Fe}$ and around
$4.9 \mathrm{mg} \mathrm{g}^{-1}$ for Al oxyhydroxides. At TWDEF, conifer soils had lower non-crystalline and crystalline Fe oxide concentrations (around $2.2 \mathrm{mg} \mathrm{g}^{-1}$ non-crystalline Fe oxides for aspen vs. $1.2 \mathrm{mg}$ $\mathrm{g}^{-1}$ for conifers, and around $3.7 \mathrm{mg} \mathrm{g}^{-1}$ crystalline Fe for aspen vs. $3.1 \mathrm{mg} \mathrm{g}^{-1}$ for conifers), while the $\mathrm{Al}$ concentrations were similar (Table 1). The largest measured differences between aspen and conifer soils were in terms of $\mathrm{C}$ concentration and $\mathrm{pH}$, which were always lower under conifers, with differences ranging from $0.3-0.6$ percentage points for $C$, and $0.1-0.7$ units for $\mathrm{pH}$ (Table 1). The main soil difference between sites was in the concentrations of non-crystalline and crystalline $\mathrm{Fe}$ and $\mathrm{Al}$ oxyhydroxides, which were three to four times higher at CM. The higher oxyhydroxide concentration also corresponded to higher $\mathrm{C}$ concentrations at CM compared to TWDEF with differences ranging from 1.9 to 2.3 percentage points. At both sites, C concentrations in the topsoils were approximately 2 percentage points higher than in the corresponding subsoils (Table 1).

\section{Leachate Characterization}

Aspen leaves $(\mathrm{AL})$ yielded the highest DOC concentration among leachates (136 mg DOC $\mathrm{g}^{-1}$ substrate), while the other three substrates released ten times less DOC per gram of material (Table 2). Leachates from foliage had approximately two to three times higher total $N$ values than corresponding root leachates, even though root biomass itself had higher $(0.95 \%$ vs. $0.58 \%$ for $\mathrm{AR}$ and $\mathrm{AL}$ ) or similar (0.5\% vs. $0.45 \%$ for $\mathrm{CR}$ and $\mathrm{CN}) \mathrm{N}$ concentrations. The leachates had similar SUVA values -0.8 to 1.1. AL had the lowest HIX value (0.06) suggesting higher $\mathrm{H}: \mathrm{C}$ ratios and a more aliphatic nature of the solution compared to the other leachates, and the highest FI index (2.01). Foliar leachates had higher FI than those derived from roots (Table 2).

We created a 4-component PARAFAC model, which validated via split-half analysis, and after normalization of the input data, accounted for $98.7 \%$ of the observed variation in DOC fluorescence. From the four components of the PARAFAC model the first two (C1 and $\mathrm{C} 2$ ) were identified as humic-like (similar to C3 and C2 in Stedmon et al., 2007) while C3 and C4 were protein-like (C4 similar to peak in panel X8 in Murphy et al., 2011; C3 similar to C4 in Gueguen et al., 2014). Intensities reported in Table 2 for each component (C1 - C4) indicate that the fluorescence signal of $\mathrm{AL}$ was almost entirely explained by $\mathrm{C} 4(86.5 \%)$, while the remaining components explained only $13.5 \%$. By contrast, $\mathrm{C} 4$ had very small intensities in the AR and $\mathrm{CN}$ leachates and was entirely missing from the CR leachate. For $\mathrm{AR}$ and $\mathrm{CN}$, the protein-like $\mathrm{C} 3$ explained most of the fluorescence (67 and 54\%, respectively), followed by the humiclike components $\mathrm{C} 1$ and $\mathrm{C} 2$. For $\mathrm{CR}, \mathrm{C} 1$ and $\mathrm{C} 3$ explained similar proportions of fluorescence (40 and 37\%), and C2 explained the rest.

After $24 \mathrm{~h}$ of shaking, the raw intensities of the leachate solutions decreased (data not shown) due to a decrease in DOC concentration, but the relative contribution of each component did not change with mineralization. For the AL leachate, HIX did not change but it increased for the other three leachates to an end-value of 1.17 for $\mathrm{AR}, 1.34$ for $\mathrm{CN}$, and 2.99 for CR. Conversely, the FI decreased significantly for AL (1.87), but remained fairly constant for the other three leachates (end-value 
TABLE 2 | Selected properties of plant biomass and pre-sorption leachates derived from foliage and root biomass (C1-C4 are four components of the PARAFAC model and values are percentages of total fluorescence).

\begin{tabular}{|c|c|c|c|c|c|c|c|c|c|c|c|c|c|}
\hline & \multicolumn{3}{|c|}{ Biomass } & \multicolumn{10}{|c|}{ Leachates } \\
\hline & $\mathrm{C} \%$ & N\% & $\mathrm{C} / \mathrm{N}$ & $\begin{array}{c}\text { mg DOC g-1 } \\
\text { substrate }\end{array}$ & $\begin{array}{c}\text { mg total } N \\
\mathbf{g}^{-1} \text { substrate }\end{array}$ & $\mathrm{pH}$ & HIX & $\begin{array}{l}\text { SUVA L mg } \\
\mathrm{C}^{-1} \mathrm{~m}^{-1}\end{array}$ & $\mathbf{F I}$ & C1 & $\mathrm{C} 2$ & C3 & C4 \\
\hline $\mathrm{AL}$ & 43 & 0.58 & 74 & 136 & 0.94 & 5.6 & 0.06 & 0.9 & 2.01 & 5.9 & 0.2 & 7.4 & 86.5 \\
\hline AR & 38 & 0.95 & 40 & 10.9 & 0.53 & 6.7 & 0.37 & 0.8 & 1.41 & 20.2 & 11.9 & 66.6 & 1.3 \\
\hline $\mathrm{CN}$ & 43 & 0.45 & 96 & 10.5 & 0.75 & 6.5 & 0.73 & 0.8 & 1.84 & 28.8 & 14.1 & 54.3 & 2.8 \\
\hline CR & 40 & 0.50 & 80 & 11 & 0.24 & 6.2 & 0.58 & 1.1 & 1.51 & 40.3 & 22.9 & 36.9 & 0 \\
\hline
\end{tabular}

1.47 for $\mathrm{AR}, 1.9$ for $\mathrm{CN}$, and 1.5 for CR). SUVA almost doubled for all leachates with end-values of 1.2 for AL, 1.8 for AR, 1.8 for $\mathrm{CN}$, and 2.3 for CR.

\section{DOC Retention/Release}

The sorption isotherms depicted in Figures 2, 3 were adjusted for the amount of DOC mineralized and released as $\mathrm{CO}_{2}$ (exact values are reported in the Supplementary Materials 2, 3). On average, more DOC was lost through mineralization in the root leachate treatments than foliage treatments $-13 \%$ of added $\mathrm{C}$ mineralized for AL treatment vs. $18 \%$ for AR, $12 \%$ for CN vs. $18 \%$ for CR. Overall, similar proportions of DOC were mineralized in aspen and conifer soils (16 and 15\%, respectively).

The sorption behavior of leachate types was significantly different based on all four sorption metrics analyzed - the curve parameters ( $n$ and $k$ ) and NPC and EP (Table 3). Post hoc Tukey's HSD test indicated statistically significant differences between AL and AR in regard to all four parameters analyzed, but no significant differences were detected between $\mathrm{CN}$ and $\mathrm{CR}$ (Table 4). Figures 2, 3 show the similarities between CN and CR on almost all soils, while the sorption isotherms diverge much more strongly between AL and AR.

Based on the sorption isotherm parameters $k$ and $n, \mathrm{AL}$ had the steepest sorption isotherms, suggesting the highest retention. This was followed by $\mathrm{CN}>\mathrm{CR}>\mathrm{AR}$ (Table 4), with the latter two being significantly different from AL. Overall, AL had the lowest NPC (DOC concentration where net retention $=$ net release) and the highest EP ( $C$ retained at highest DOC concentration added) values. For NPC, the only significant difference was between AL and AR, while for EP, AL differed significantly from AR and CN (Table 4).

One of the most interesting findings of this study was the consistently higher DOC retention in aspen soils compared to conifer soils, irrespective of the source of DOC (Table 4). For a given leachate type, aspen soils reached NPC at lower DOC concentrations, i.e., they started to retain $\mathrm{C}$ at lower DOC concentrations and had overall higher EP values. Conifer soils often did not reach NPC with the DOC concentrations used in this study, especially for topsoils. The ANOVA on curve parameters corroborated this observation for NPC, EP, and $n$ (Tables 3, 4). The lower $n$ values for aspen soils indicated steeper retention curves than for conifer soils, i.e., greater sorption.

Null point concentration and curve shape (parameter $n$ ) differed significantly between top- and subsoil (Table 3 ). The lower $n$ values for topsoils were associated with similar $k$ values
(Table 4), indicating steeper curves for topsoils, i.e., higher retention rates. However, the steeper curves did not result in lower NPC, as topsoils on average had significantly higher NPC values than subsoils (Tables 3, 4).

The ANOVA results showed that the only significant difference between sites was for parameter $k$ (Table 3). It was larger for CM than TWDEF (Table 4), again indicating higher DOC retention rates in CM.

We found statistically significant interactions between leachate type and soil type for parameter $k$, and between depth and soil type for EP (Table 3). The interaction between leachate type and soil type for parameter $k$ was due to the fact that root-derived DOC had higher $k$ in aspen soils (20.9 for AR and 27.4 for CR on aspen soils, and 11.5 for AR and 25.4 for CR on conifer soils), and foliage DOC had higher $k$ in conifer soils (60.2 for $\mathrm{AL}$ and 47.6 for $\mathrm{CN}$ on conifer soils and 45.4 for $\mathrm{AL}$ and 36 for $\mathrm{CN}$ on aspen soils). The interaction between depth and soil type for EP indicates that maximum retention was higher in aspen topsoils than in aspen subsoils $\left(126.5 \mathrm{mg} \mathrm{C} \mathrm{kg}^{-1}\right.$ soil and $80 \mathrm{mg} \mathrm{C} \mathrm{kg}^{-1}$ soil, respectively), while in conifer soils the depth pattern was the opposite. No statistically significant relationships were found between native concentration of SOC and any of the different sorption parameters.

\section{Post-sorption DOC Quality}

We calculated fluorescence indices and PARAFAC components to evaluate the effect of leachate quality on DOM sorption patterns. FI values of the sorption solutions did not change in relation to initial DOC concentration and overall ranged from 1.39 to 1.6 for all soils irrespective of the leachate treatment. HIX values (high values mean greater degree of humification and a low $\mathrm{H}: \mathrm{C}$ ratio) at the lowest initial DOC concentrations (10, $20 \mathrm{mg} \mathrm{DOC} \mathrm{L}^{-1}$ ) reflected a soil signature (expressed as

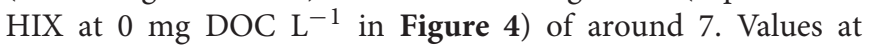
these concentrations were also distinctly different from the preand post-sorption leachate baseline $(<1$ for $\mathrm{AL}, \mathrm{AR}$ and $\mathrm{CN}$, and $<3$ for CR; Figure 4). At the initial DOC concentration of around $40 \mathrm{mg} \mathrm{L}^{-1}$ the average HIX decreased to 3 for AL, 2.8 for $\mathrm{AR}, 3$ for $\mathrm{CN}$, and 4.4 for $\mathrm{CR}$. We found no statistically significant differences between HIX values from solutions of aspen and conifer soils.

SUVA values stayed relatively constant for all concentrations of $\operatorname{AR}(2.3 \pm 0.13)$, and decreased slightly for $\mathrm{CN}$ and $\mathrm{CR}$ (from 2.3 in the $\mathrm{KCl}$ treatment to 1.8 at $80 \mathrm{mg} \mathrm{DOC} \mathrm{L}^{-1}$ ). For $\mathrm{AL}$, SUVA values initially increased from 2.3 to 2.9 at concentrations 

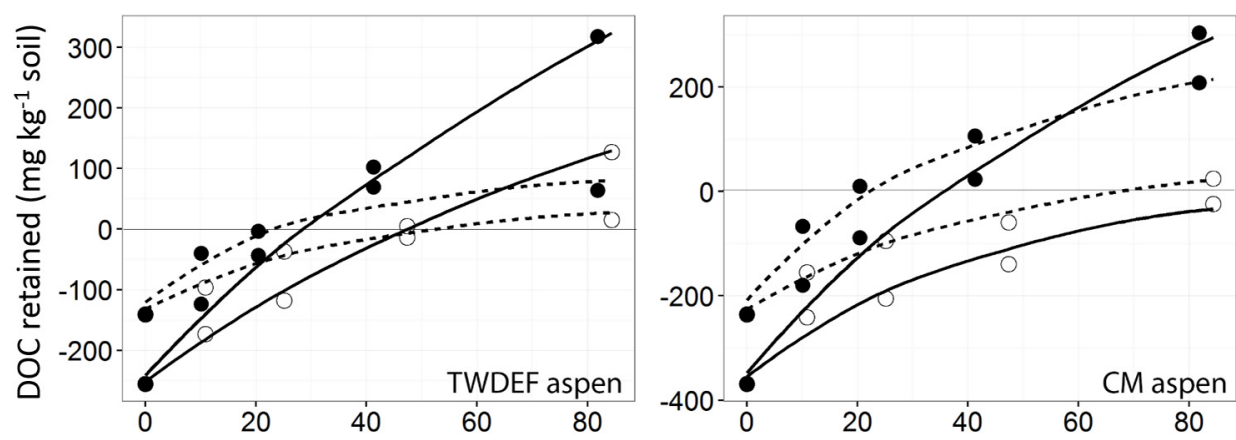

\section{Substrate}

- $A L$

OAR

Depth

$-0-10$

- $40-50$
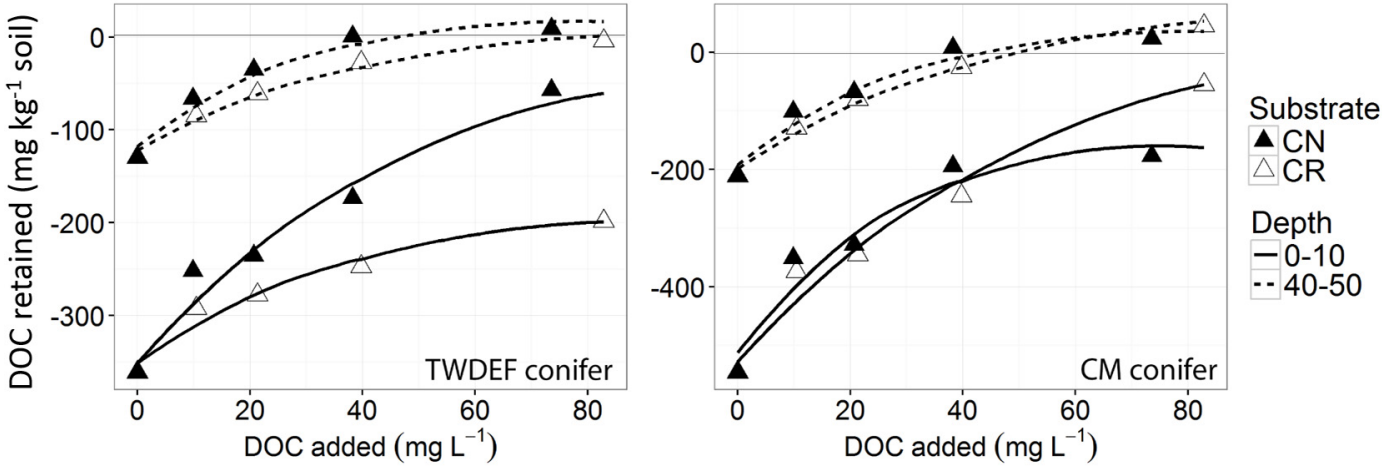

FIGURE 2 | Non-linear isotherms representing release/retention of dissolved organic carbon (DOC) from aspen leaves (AL) and aspen roots (AR) on aspen soils (upper two graphs), and of fir needles (CN) and fir roots (CR) on conifer soils (lower two graphs) from TWDEF and CM sites. The $y$-axis indicates DOC retention in the area above zero, and DOC release in the area below the zero-line. The SE of laboratory replicates was mostly < $5 \%$.
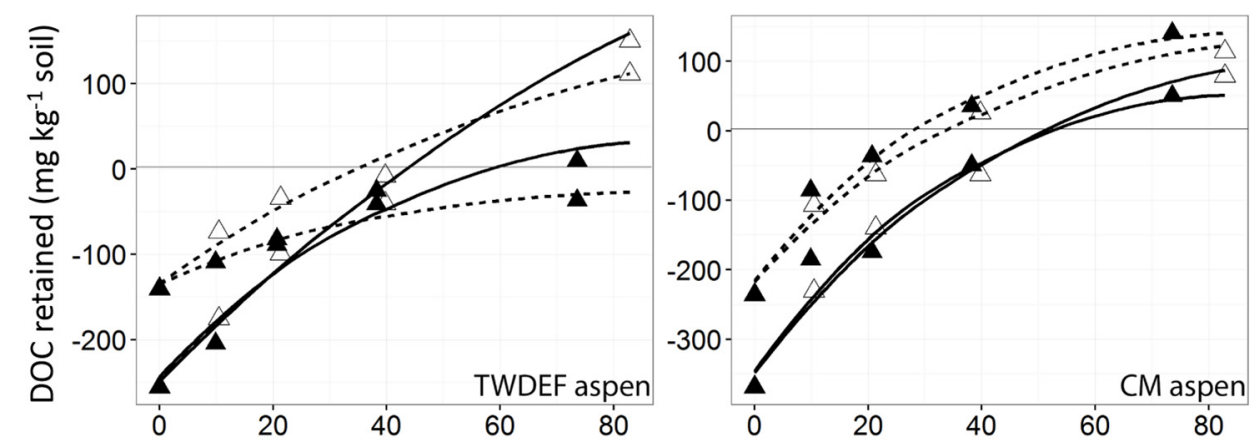

\section{Substrate}

$\triangle \mathrm{CN}$

$\triangle \mathrm{CR}$

Depth

$-0-10$

$-.40-50$
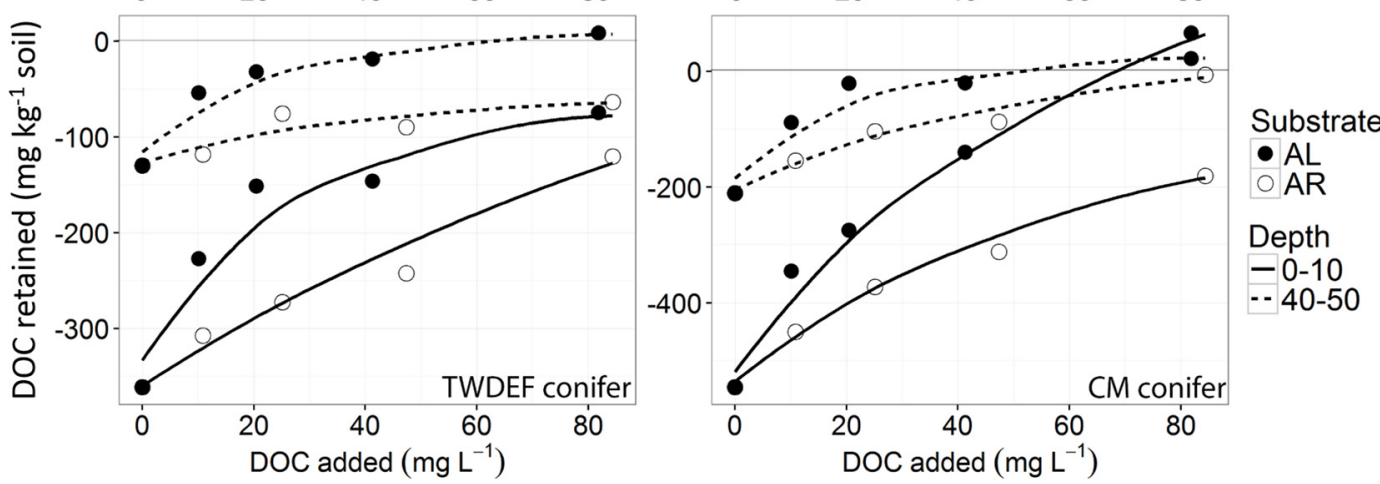

FIGURE 3 | Non-linear isotherms representing release/retention of dissolved organic carbon (DOC) from fir needles (CN) and fir roots (CR) on aspen soils (upper two graphs), and of aspen leaves (AL) and aspen roots (AR) on conifer soils (lower two graphs) from TWDEF and CM sites. The $y$-axis indicates DOC retention in the area above zero, and DOC release in the area below the zero-line. The SE of laboratory replicates was mostly $<5 \%$. 
TABLE 3 | ANOVA summary table for calculated sorption parameters (Bolding indicates statistically significant differences at $\alpha=0.05$ ).

\begin{tabular}{|c|c|c|c|c|c|c|c|c|c|}
\hline & \multirow[b]{2}{*}{ df } & \multicolumn{2}{|c|}{$k$} & \multicolumn{2}{|c|}{$n$} & \multicolumn{2}{|c|}{ NPC } & \multicolumn{2}{|c|}{ EP } \\
\hline & & $\boldsymbol{F}$ & $p$ & $\boldsymbol{F}$ & $p$ & $\boldsymbol{F}$ & $p$ & $\boldsymbol{F}$ & $p$ \\
\hline Leachate & 3,13 & 21.9 & $<0.01$ & 7.32 & $<0.01$ & 3.77 & 0.04 & 8.34 & $<0.01$ \\
\hline Soil type & 1,13 & 0.01 & 0.94 & 6.8 & 0.02 & 23 & $<0.01$ & 48.7 & $<0.01$ \\
\hline Depth & 1,13 & 0.07 & 0.79 & 13.9 & $<0.01$ & 5.95 & 0.03 & 1.76 & 0.21 \\
\hline Site & 1,13 & 33.9 & $<0.01$ & 0.26 & 0.62 & 1.7 & 0.22 & 1.19 & 0.3 \\
\hline Leach $\times$ Soil & 3,13 & 3.86 & 0.04 & 2.43 & 0.11 & 0.92 & 0.46 & 1.57 & 0.24 \\
\hline Leach $\times$ Depth & 3,13 & 1.05 & 0.4 & 2.15 & 0.14 & 0.84 & 0.49 & 2.81 & 0.08 \\
\hline Leach $\times$ Site & 3,13 & 1.84 & 0.19 & 1.24 & 0.34 & 0.19 & 0.9 & 1.05 & 0.4 \\
\hline Soil $\times$ Depth & 1,13 & 0.75 & 0.4 & 0.01 & 0.92 & 1.52 & 0.24 & 12.1 & $<0.01$ \\
\hline Soil $\times$ Site & 1,13 & 0.28 & 0.61 & 1.23 & 0.29 & 1.46 & 0.25 & 0.09 & 0.77 \\
\hline Depth $\times$ Site & 1,13 & 0.48 & 0.5 & 1.64 & 0.22 & 0.76 & 0.4 & 2.63 & 0.13 \\
\hline
\end{tabular}

$k$ and $n$ are curve fitting parameters. NPC, null point concentration; EP, endpoint.

TABLE 4 | Average values \pm standard error of the mean of calculated parameters for each level of each main effect (Bolding indicates statistically significant differences at $\alpha=0.05$; letters indicate differences between levels of a factor).

\begin{tabular}{|c|c|c|c|c|c|}
\hline Factors & Levels & $k$ & $n$ & NPC (mg L ${ }^{-1}$ initial DOC) & $\mathrm{EP}$ (mg C kg ${ }^{-1}$ soil) \\
\hline \multicolumn{6}{|l|}{ Site } \\
\hline & TWDEF & $24.8 \pm 4.5$ & $2.09 \pm 0.19$ & $116.8 \pm 32.1$ & $160 \pm 30.3$ \\
\hline & $\mathrm{CM}$ & $43.8 \pm 5.1$ & $2.11 \pm 0.15$ & $74.3 \pm 12.3$ & $39.6 \pm 30.8$ \\
\hline \multicolumn{6}{|l|}{ Depth } \\
\hline & $0-10$ & $35.0 \pm 5.6$ & $1.84 \pm 0.14$ & $118.0 \pm 28.9$ & $13.44 \pm 39.4$ \\
\hline & $40-50$ & $33.6 \pm 5.1$ & $2.36 \pm 0.18$ & $73.1 \pm 18.4$ & $42.15 \pm 17.5$ \\
\hline \multicolumn{6}{|c|}{ Soil type } \\
\hline & Aspen & $32.4 \pm 4.2$ & $1.88 \pm 0.11$ & $51.1 \pm 6.9$ & $103.2 \pm 26.2$ \\
\hline & Conifer & $36.2 \pm 6.3$ & $2.31 \pm 0.20$ & $140.0 \pm 30.6$ & $-47.7 \pm 20.9$ \\
\hline \multicolumn{6}{|c|}{ Leachate } \\
\hline & $\mathrm{AL}$ & $52.8 \pm 6.2^{a}$ & $2.61 \pm 0.35^{a}$ & $57.6 \pm 18.1^{a}$ & $114.3 \pm 51.1^{a}$ \\
\hline & $A R$ & $16.2 \pm 3.0^{c}$ & $1.67 \pm 0.12^{c}$ & $126.0 \pm 32.4^{b}$ & $-28.4 \pm 33.4^{b}$ \\
\hline & $\mathrm{CN}$ & $41.8 \pm 8.3^{a b}$ & $2.27 \pm 0.17^{a b}$ & $83.4 \pm 19.9^{a b}$ & $-4.8 \pm 32.4^{b}$ \\
\hline & $\mathrm{CR}$ & $26.4 \pm 4.3^{b}$ & $1.85 \pm 0.12^{b c}$ & $115.3 \pm 56.1^{a b}$ & $30.07 \pm 40.4^{a b}$ \\
\hline
\end{tabular}

$k$ and $n$ are curve fitting parameters. NPC, null point concentration; EP, endpoint.

0,10 , and $20 \mathrm{mg} \mathrm{L}^{-1}$, and decreased to 2.4 and 1.8 at higher concentrations (40 and $80 \mathrm{mg} \mathrm{L}^{-1}$, respectively).

The non-parametric comparison of fluorescence components for all main effects (Table 5) showed that the humic $\mathrm{C} 1$ peak and protein-like C3 and C4 peaks differed significantly by leachate type. $\mathrm{C} 1$ proportion was highest for $\mathrm{CR}$ and $\mathrm{C} 3$ was highest for $\mathrm{CN}$, while both constituted the smallest proportion of total fluorescence in samples treated with AL (Table 6). Most samples treated with $\mathrm{AL}$ were dominated by $\mathrm{C} 4$, which was much less abundant or completely absent in samples treated with the other leachates (Table 6). Overall C4 was absent in 40\% of all samples, mostly from the CR treatment (missing in 80\%). The proportion of C4 was highest in samples treated with the highest AL DOC concentrations and was missing in a few topsoil samples treated with the lowest AL DOC concentrations. On average, AL treated subsoils had 13 percentage-point higher C4 proportions than topsoils. Overall, AL treated samples showed a high variability between individual component proportions due to different responses of top- and subsoils (Supplementary Figure 11).
The proportions of all components differed significantly by depth (Tables 5, 6). Topsoils had higher proportions of $\mathrm{C} 1$ and $\mathrm{C} 2$ than subsoils. In contrast the proportion of $\mathrm{C} 3$ was higher for subsoils than topsoils. C2 also differed significantly between sites, with $\mathrm{CM}$ soils having higher proportions compared to TWDEF soils (Table 6).

The proportions of the first two components showed a similar trend with initial DOC, as did HIX (Supplementary Figures 3, 4). This means that for $\mathrm{C} 1$ and $\mathrm{C} 2$ the proportions decreased with increasing initial DOC concentration by 12 and 10 percentagepoints, respectively. In contrast, for the protein-like C3 and C4 the proportions increased by, on average, 17 (for $\mathrm{AR}, \mathrm{CN}, \mathrm{CR}$ ) and 30 (for $\mathrm{AL}$ ) percentage-points, respectively.

\section{DOC Desorption}

In the final step we evaluated whether and to what extent there was a difference in the strength with which the sorbed SOC was held in the soils. As seen by the $y$-axis intercepts in Figure 2, aspen SOC was generally less water soluble than conifer SOC, 

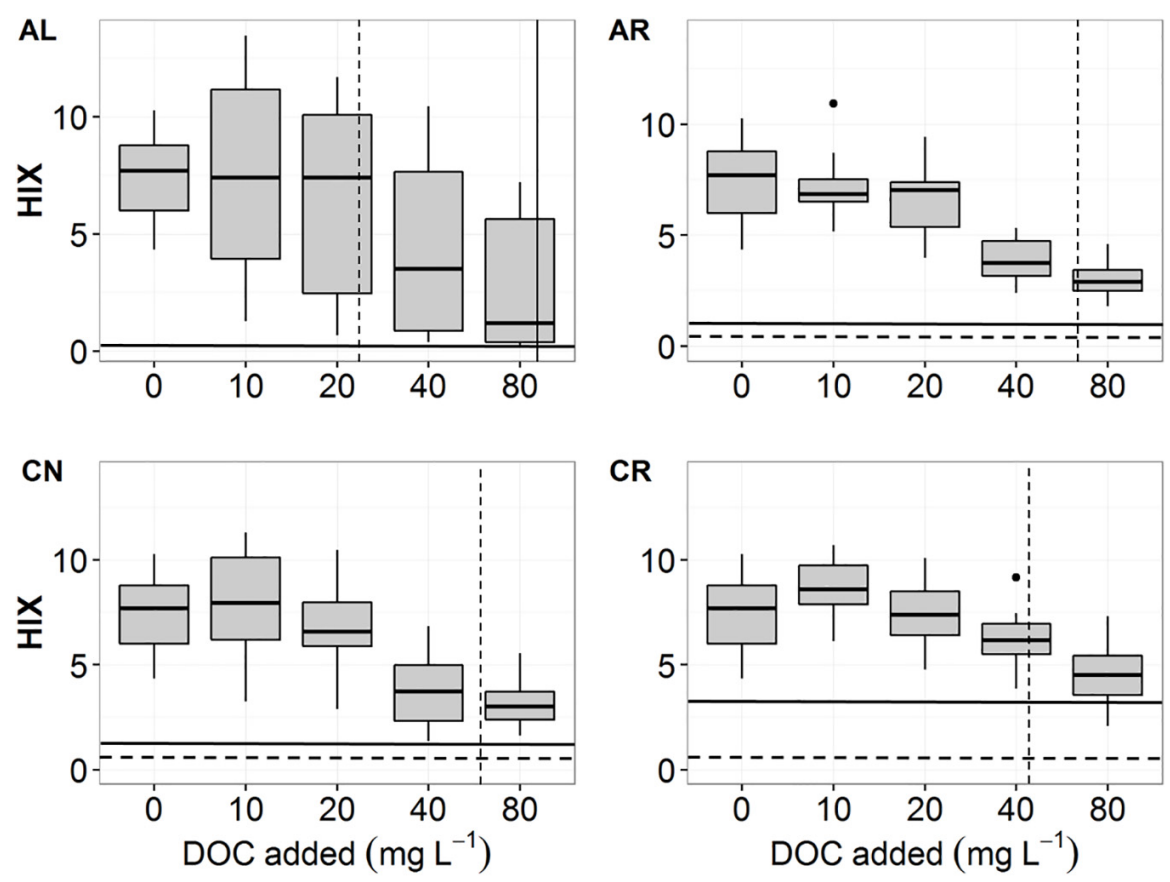

FIGURE 4 | HIX values of post-sorption solutions for all four leachates - AL, AR, CN, CR. The dashed horizontal lines indicate HIX values of fresh, pre-sorption leachates $(A L=0.06, A R=0.37, C N=0.73, C R=0.58)$. The solid horizontal lines indicate HIX values for pure leachates after $24 \mathrm{~h}$ of shaking $(A L=0.06, A R=1.17$, $C N=1.34, C R=2.99$ ). The dashed vertical lines indicate the average NPC for aspen soils $(A L=24.6, A R=70.4, C N=65.2, C R=44.2 m g ~ L-1)$. Average $N P C$ for conifer soils is indicated with a solid vertical line for $A L\left(A L=90.5 \mathrm{mg} \mathrm{L}^{-1}\right)$, but could not be visualized for the other leachates due to being out of range $(A R=181.5$, $\mathrm{CN}=101.7, \mathrm{CR}=186.4 \mathrm{mg} \mathrm{L}^{-1}$ ).

TABLE 5 | Kruskal-Wallis test result summary for fluorescence components in post-sorption DOM samples (Bolding indicates statistically significant differences at $\alpha=0.05)$.

\begin{tabular}{|c|c|c|c|c|c|c|c|c|c|}
\hline & \multirow[b]{2}{*}{ df } & \multicolumn{2}{|c|}{ C1 } & \multicolumn{2}{|c|}{$\mathrm{C} 2$} & \multicolumn{2}{|c|}{ C3 } & \multicolumn{2}{|c|}{ C4 } \\
\hline & & $x^{2}$ & $p$ & $x^{2}$ & $p$ & $x^{2}$ & $p$ & $x^{2}$ & $p$ \\
\hline Leachate & 3 & 9.33 & 0.025 & 2.58 & 0.46 & 19.51 & $<0.01$ & 15.59 & $<0.01$ \\
\hline Soil type & 1 & 0.07 & 0.79 & 1.84 & 0.17 & 0.02 & 0.88 & 0.24 & 0.62 \\
\hline Depth & 1 & 12.82 & $<0.01$ & 11 & $<0.01$ & 3.84 & 0.05 & 8.9 & $<0.01$ \\
\hline Site & 1 & 1.74 & 0.19 & 10.51 & $<0.01$ & 2.27 & 0.13 & 2.89 & 0.09 \\
\hline
\end{tabular}

despite higher intrinsic SOC levels in aspen soils than conifer soils (Table 1). On average, the desorption of this intrinsic SOC with

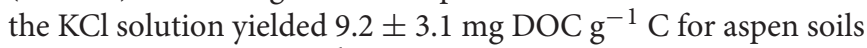
vs. $14 \pm 5.6 \mathrm{mg} \mathrm{DOC}^{-1} \mathrm{C}$ for conifer soils.

In the single-step desorption following the sorption experiment (after 7 days of drying), aspen and conifer soils released similar DOC concentrations $\left(3 \pm 1.8 \mathrm{mg}\right.$ DOC $\mathrm{L}^{-1}$ from aspen soils and $3.6 \pm 3.5 \mathrm{mg} \mathrm{L}^{-1}$ from conifer soils). However, as sorption on conifer soils was much weaker than on aspen soils, absolute retention was still almost twice as high

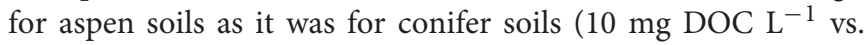

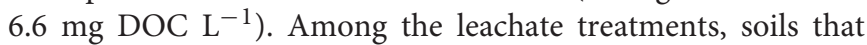
had been treated with AL showed the lowest desorption with $2.2 \pm 2 \mathrm{mg} \mathrm{L}^{-1}$, while the other treatments released higher DOC concentrations with $3.6 \pm 2.6 \mathrm{mg} \mathrm{L}^{-1}$ for $\mathrm{AR}, 3.4 \pm 2.7 \mathrm{mg} \mathrm{L}^{-1}$ for $\mathrm{CN}$, and $4.1 \pm 3 \mathrm{mg} \mathrm{L}^{-1}$ for $\mathrm{CR}\left(p=0.04, F_{3,112}=2.84\right)$.
The soil solutions after the desorption process had changed qualitatively, and had increased HIX values - AL 18.01 \pm 2.6 , AR $12.3 \pm 1.8, \mathrm{CN} 10.8 \pm 2.1, \mathrm{CR} 12.5 \pm 3.8$ - compared to any of the sorption solutions shown in Figure 4. Similarly to HIX, SUVA values also increased from an average of $2.2 \pm 0.18$ to $4.1 \pm 0.37$ for all leachate treatments, substantiating a shift to a more aromatic composition. The FI values of the solution did not change from the ones found after the sorption process (on average 1.5).

In contrast to the sorption samples the fluorescence indices in the desorption samples were overall similar among all soils and treatments, suggesting a similar quality of the SOM in solution. The proportion of the first two fluorescence components (C1 and C2) was higher in desorption samples (49 $\pm 2 \%$; $43 \pm 5 \%$, respectively) than sorption samples at various initial concentrations of DOC ( $44 \pm 8 \% ; 30 \pm 9 \%$, respectively). In 
TABLE 6 | Average values \pm standard error of calculated fluorescence parameter proportions for each level of each main effect (Bolding indicates statistically significant differences at $\alpha=0.05$; letters indicate differences between levels of a factor).

\begin{tabular}{|c|c|c|c|c|c|}
\hline \multirow[t]{2}{*}{ Factors } & \multirow[t]{2}{*}{ Levels } & C1 & \multirow[t]{2}{*}{$\mathrm{C} 2$} & \multirow[t]{2}{*}{ C3 } & \multirow[t]{2}{*}{ C4 } \\
\hline & & $\%$ & & & \\
\hline \multicolumn{6}{|l|}{ Site } \\
\hline & TWDEF & $42 \pm 1.5$ & $26 \pm 1.3$ & $19 \pm 1.4$ & $14 \pm 3.1$ \\
\hline & $\mathrm{CM}$ & $46 \pm 0.9$ & $35 \pm 1.1$ & $14 \pm 1$ & $5.4 \pm 1.8$ \\
\hline \multicolumn{6}{|l|}{ Depth } \\
\hline & $0-10$ & $48 \pm 0.7$ & $35 \pm 0.9$ & $14 \pm 0.9$ & $3 \pm 1.3$ \\
\hline & $40-50$ & $39 \pm 1.4$ & $26 \pm 1.4$ & $19 \pm 1.5$ & $16 \pm 3.2$ \\
\hline \multicolumn{6}{|l|}{ Soil type } \\
\hline & Aspen & $45 \pm 1$ & $33 \pm 1.2$ & $16 \pm 1.2$ & $6.8 \pm 2.1$ \\
\hline & Conifer & $43 \pm 1.4$ & $28 \pm 1.4$ & $17 \pm 1.3$ & $12 \pm 2.9$ \\
\hline \multicolumn{6}{|l|}{ Leachate } \\
\hline & $A L$ & $37 \pm 2.7^{a b}$ & $24 \pm 2.9$ & $8 \pm 0.8^{a}$ & $31 \pm 5.8^{a}$ \\
\hline & $A R$ & $44 \pm 1^{b}$ & $32 \pm 1.1$ & $18 \pm 1.4^{b}$ & $5 \pm 0.8^{b}$ \\
\hline & $\mathrm{CN}$ & $44 \pm 1.2^{b}$ & $31 \pm 1.4$ & $23 \pm 2.1^{b}$ & $2 \pm 0.4^{b}$ \\
\hline & $\mathrm{CR}$ & $49 \pm 0.6^{a}$ & $35 \pm 0.9$ & $16 \pm 1.4^{b}$ & $0.3 \pm 0.1^{c}$ \\
\hline
\end{tabular}

contrast, there was a decline in $\mathrm{C} 3$ from the sorption samples $(16 \pm 7 \%)$ to desorption solutions $(6 \pm 4 \%)$. The average proportion of $\mathrm{C} 4$ in the desorption samples ranged from 1.2 to $2.6 \%$, with almost half of the samples completely lacking C4 (even the soils treated with $\mathrm{AL}$ ), and the other half showing extremely small intensities ( $<5 \%$ of total fluorescence). None of the components in the desorption samples were significantly different as a function of leachate, soil type, and site. The proportion of $\mathrm{C} 1$ was significantly higher for topsoil than subsoil $\left(50 \pm 1.5 \%\right.$ vs. $\left.48 \pm 2 \% ; \chi^{2}=11.25, p<0.01\right)$.

\section{DISCUSSION}

Understanding how tree species affect SOC pools is crucial for building better $\mathrm{C}$ models and reaching various ecosystemservice goals. This is true especially now, when the distribution of tree species is changing at local and global scales due to climate change and forest management practices (McKenney et al., 2007; IPCC, 2019 - 2.2.4). SOC under aspen forests has been shown to be more stable compared to adjacent conifer forests in various studies in North America (as reviewed by Laganière et al., 2017). The results of our study indicate that this stability might be due to enhanced sorption of DOC from aspen foliage. Furthermore, aspen DOM seems to help create mineral soil conditions that are more favorable to the sorption of incoming DOC, irrespective of the source.

Most sorption parameters in this study indicated that DOC derived from aboveground litter (foliage and needles) showed a higher retention than DOC of root leachates. The magnitude of this was, however, different for the two species. While the retention of $\mathrm{AL}$ differed significantly from the retention of $\mathrm{AR}$, $\mathrm{CN}$ (subalpine fir needles) had only a slightly higher sorption than CR (subalpine fir roots). This, along with similar results for conifers reported by Hansson et al. (2010), suggests that the relative contribution of foliage and root DOC to mineralassociated organic matter can differ based on the tree species that dominate a forest stand. For aspen soils, the DOC contribution to mineral-associated SOC is most likely dominated by foliage leachates, while in conifer soils the contribution is represented by an equal mix of both.

The soils sampled from aspen and conifer stands in this study had similar soil mineral properties, and the soil horizons sampled (ABt and BAt in aspen and Bt in conifer soils at TWDEF) differed mostly in regard to the amount and type (aspen vs. conifer) of organic matter. Thus, the higher sorption and lower desorption in aspen soils, irrespective of the leachate type added, indicates that this effect is likely caused by SOM properties. The effect occurred even though aspen soils had higher SOC concentrations and was also more pronounced in the topsoils (steeper sorption slopes and higher maximum retention), which are more C-rich than subsoils.

\section{Detritus and Soil DOM Quality}

To test the hypothesis that DOM quality drives the sorption of DOM in mineral soil, we calculated various spectroscopic indices - SUVA, HIX, FI, and fluorophores from a PARAFAC model - and measured DOC and TN concentrations, and $\mathrm{CO}_{2}$ release during the shaking process in the batch sorption experiment. The results did not always point in the same direction. In general, SUVA and HIX values indicated an aliphatic and labile nature of all plant leachates. FI suggested a more microbially derived nature of the foliage than root leachates. The leachate from aspen leaves stood out from the others in terms of HIX, FI, and the fluorescence components. They suggested that AL was of a more aliphatic nature than the other leachates. The DOC/TN ratio was, however, much higher for AL (145), and the mineralization of AL (not mixed with soil) was similar to the mineralization of $\mathrm{CN}$ leachates (similar proportion of DOC mineralized).

The high proportion of the protein-like C4 fluorescence component in AL clearly distinguished this leachate type from the others. The high C:N ratio (145) of the AL solution makes it unlikely, however, that this component was dominated by 
protein-like compounds. Other compounds, like tannins and lignin phenols, have been found to fluoresce with similar spectral signatures to proteins and amino acids (Aiken, 2014). Even though aspen foliage leachate has been found to contain much higher amounts of phenolic compounds compared to conifer needles (Startsev et al., 2008), the low HIX and high FI values indicate a highly aliphatic nature of AL leachates, which in turn would rule out high aromatic compound concentrations. Dominance of protein-like components in leachates of senesced litter together with low HIX and high FI has also been reported by Beggs and Summers (2011). Similar to our study, Beggs and Summers (2011) found that a similar protein-like peak to C4 was lost due to biodegradation from leachate formed from dead needles that had not been shed by the tree. Meanwhile, needles collected from the O-horizon in their study did not loose this component with biodegradation, suggesting different chemistry of the fluorophores representing this component. Overall, while a few studies have examined the fluorescence spectra of plant leachates with PARAFAC models (Beggs and Summers, 2011; Cuss et al., 2014; Wheeler et al., 2017), any interpretation of the protein-like peaks is still based on aquatic research findings in fresh or marine waters. Thus, there is a need to evaluate the assumption of amino acid contribution to the proteinlike peaks with more detailed chemical composition data from terrestrial DOM.

Fluorescence indices for the description of leachate-soil exchange processes were only of limited value. The HIX values at small initial-DOC concentrations were similar to the soil-HIX signature ( $\mathrm{KCl}$ solution treatment), which indicated that the soilleachate mixture was mostly dominated by the desorbed SOM (Figure 3 and Supplementary Figures 3-6). The high proportion of $\mathrm{C} 1$ and $\mathrm{C} 2$ components in these solutions, which suggest a highly processed DOM nature, also confirmed this. At higher initial-DOC concentrations, the plant signature (solid horizontal line in Figure 4) became more dominant, and the solutions had high proportions of the protein-peaks $\mathrm{C} 3$ for $\mathrm{AR}, \mathrm{CN}, \mathrm{CR}$, and $\mathrm{C} 4$ for AL. The soil-leachate mixture, however, never acquired a purely plant-like signature, suggesting that even at high DOC concentrations, where sorption should be favored, desorption of native SOM occurred.

\section{Leachate and Soil Interactions}

In a field study conducted at TWDEF (Boča and Van Miegroet, 2017), we measured higher DOC concentrations and losses between 5 and $45 \mathrm{~cm}$ depths under conifers. The SOC pools under conifer stands were, however, much smaller than under aspen stands. This experiment elucidated why field DOC levels might not be good indicators for DOC sorption and SOC stocks in the aspen-conifer forests in Utah. The lower NPC of AL in aspen soils (25.8 and $19.9 \mathrm{mg} \cdot \mathrm{L}^{-1}$ in top- and subsoil, respectively) suggests that high concentrations are not necessary for the retention of $\mathrm{AL}$ DOC to occur in these soils. Conversely, the high NPC of subalpine fir leachates on conifer soils (102.4 and $52.1 \mathrm{mg} \cdot \mathrm{L}^{-1}$ for $\mathrm{CN}$ and 503.7 and $83.6 \mathrm{mg} \cdot \mathrm{L}^{-1}$ for $\mathrm{CR}$ in topand subsoil) suggests that the conifer field DOC concentrations (28.4-45.5 $\mathrm{mg} \cdot \mathrm{L}^{-1}$ under conifers and 7.3-23.8 $\mathrm{mg} \cdot \mathrm{L}^{-1}$ under aspen) might not be sufficient for DOC retention to commence in these soils. The lower sorption of subalpine fir DOC to conifer soils might suggest a lower stability of conifer SOC due to fewer mineral-organic associations. This is in agreement with results from long-term incubation experiments that have shown conifer soils having higher heterotrophic respiration than aspen soils (Giardina et al., 2001; Woldeselassie et al., 2012; Laganiére et al., 2013).

Our study does not allow us to elucidate the mechanisms behind higher DOC sorption in aspen soils. Based on other published literature we can hypothesize that the higher sorption was either due to an unmeasured property of the mineral soil or due to the properties of SOM. In regard to unmeasured properties we can only speculate that there could be differences in the very fine clays between soils that might have developed due to differing mineral weathering trajectories caused by the overlaying vegetation (Taylor et al., 2009). In regards to organic matter, one explanation could be that aspen, with their more nutrient rich foliage, facilitate a more rapid formation of mineral-associated organic matter via microbial pathways (Craig et al., 2018; Lavallee et al., 2018). Considering that aspen soils were more receptive to DOC irrespective of the source, the microbial biomass attached to minerals in patches already containing old C (Vogel et al., 2014) could be more active and/or efficient in aspen than in conifer soils. The similar proportion of mineralized DOC on both soils, found in this study, does not necessarily indicate similar carbon use efficiency, especially for substrates of contrasting quality (Manzoni et al., 2012), and, therefore, cannot exclude a difference in microbial activity in both soils. Indeed, as mentioned above, long-term laboratory incubations have shown that more SOC is mineralized in conifer soils than aspen soils (Giardina et al., 2001; Woldeselassie et al., 2012; Laganiére et al., 2013), suggesting a difference in microbial functioning. Furthermore, communitylevel physiological profiling data showed that microbial biomass increases with increasing aspen basal area (Román Dobarco et al., 2020). Finally, a second organic pathway could be organic matter precipitation by forming supramolecular organic-organic associations (Sutton and Sposito, 2005). Further studies with more detailed methods are needed to test these hypotheses.

Differences in $\mathrm{pH}$ have been commonly observed under angiosperm and gymnosperm overstories (Augusto et al., 2014), and soils in our study were no exception. Most laboratory findings assume a reduction of the sorption capacity with increasing $\mathrm{pH}$ (as reviewed by Michalzik et al., 2001). In our study, pH was slightly higher in aspen soils, which should lead to lower sorption. This, however, was not the case, suggesting that either the difference in $\mathrm{pH}$ was not big enough to cause measurable differences in sorption or the effect of DOM chemistry was stronger. In terms of potential impacts from differences in Fe oxihydroxide concentrations between the two overstory soils at TWDEF (Table 1), any effect of this parameter should remain smaller than its significance in causing differences between sampling locations. Large $\mathrm{Fe}$ and $\mathrm{Al}$ oxyhydroxide differences were observed between CM and TWDEF but sorption differed only minimally between these sites.

While in this experiment we used needles and roots only from subalpine fir, the results could still be representative of 
other conifers. The higher SOC pools under aspen compared to various conifer species in Utah (Woldeselassie et al., 2012; Román Dobarco and Van Miegroet, 2014; Boča and Van Miegroet, 2017), and higher SOC stability under aspen compared to various conifers in North America (Laganière et al., 2017), certainly point in that direction. Concomitantly, the absence of a consistently higher aspen effect on SOC pools in North America might indicate that other factors, like climate, might also control the species' effect. This could happen by climate causing variations in plant functional traits (Reich et al., 2003) or by differently affecting the strength of mechanisms for SOC accumulation.

\section{Limitations}

The initial DOC concentration in the aspen foliage leachate was ten times higher than the other leachates, indicating that freshly senesced aspen leaves contained more water-soluble compounds. These concentrations obtained under laboratory conditions were much higher than those observed in the field (Boča and Van Miegroet, 2017). While freezing of plant material can increase concentrations of dissolved organic $\mathrm{C}, \mathrm{N}$, phenolic compounds, and proteins (Kiikkilä et al., 2012), such conditions have also been observed in the natural environment, where the material was collected (Boča and Van Miegroet, 2017). We believe that grinding the biomass resulted in elevated concentrations of DOM in the leachates, but this was necessary to perform the experiment. While not completely representative of field conditions, the chosen approach for leachate generation still allows for a relative comparison of sorption between leachate types.

The NPC values from the laboratory experiment are unlikely to represent NPC values in the field due to the experimental setup (sieved soils, shaking process, and filtration). These values, however, allowed us to do a relative comparison between the sorption behavior of both soils, and they clearly showed fundamental differences between them.

\section{CONCLUSION}

In this study, we compared DOC sorption in soils of two contrasting forest overstory types - quaking aspen and conifers (subalpine fir and Douglas fir). We found that aspen soils retained more DOC than conifer soils, irrespective of the leachate type. Furthermore, aspen soils retained aspen foliage DOC especially well. While higher DOC concentrations overall increased sorption, this depended on the quality of the leachate source and the native SOC already present in soil. The findings suggest that while aspen forests have lower DOC concentrations in soil pore water measured in the field than conifers, sorption in aspen forest soils can commence at these lower concentrations. Furthermore, the study provides a foundation on which to build further investigations for understanding the exact mechanisms that allow for more efficient incorporation of labile DOM into SOC.

The results also indicate that the presence and maintenance of aspen forests in the landscape is favorable to the belowground $\mathrm{C}$ storage function of ecosystems. Encroachment by conifers into aspen stands, however, will not necessarily lead to immediate or quick soil C losses, as aspen SOC currently present in the soil is also receptive to sorption of DOC from conifer leachates. This dynamic could change in the long term if aspen SOC is replaced by conifer SOC.

\section{DATA AVAILABILITY STATEMENT}

The original contributions presented in the study are included in the article/Supplementary Material, further inquiries can be directed to the corresponding author/s.

\section{AUTHOR CONTRIBUTIONS}

$\mathrm{AJ}$ and $\mathrm{HV}$ conceived the experiment. $\mathrm{AB}, \mathrm{AJ}$, and $\mathrm{HV}$ designed the experiment. $\mathrm{AB}$ executed the experiment, conceptualized, and wrote the manuscript as lead author. All the authors contributed to the interpretation of the findings and the final manuscript.

\section{FUNDING}

This research project was supported by the Utah Agricultural Experiment Station (McIntire-Stennis, project \# UTA 1072), the Cedar Mountain Research Initiative, and Utah State University's (USU) Ecology Center. AB gratefully acknowledges the Presidential Doctoral Research Fellowship and the Dissertation Fellowship provided by USU's Office of Research and Graduate Studies, as well as the Seely-Hinckley scholarship. AJ gratefully acknowledges Utah AGricultural Experiment Station grant UTA1341. Publication UAES \#9397, Utah Agricultural Experiment Station, Utah State University, Logan, UT, United States 843224810. Publication fees were also covered by the National Science Base Funding program of Latvia.

\section{ACKNOWLEDGMENTS}

We want to thank Prof. Michelle Baker for providing access to fluorescence spectrometry equipment, Julie Kelso and Kathleen Murphy for their help in calculating and interpreting fluorescence data, and Susan Durham for her statistical advice. Further thanks go to Nicole Shepard, Garret Fry, Guilherme Benites Fernandes, and Malte Cordes for laboratory assistance in setting up and preparing the experiment. The content of this manuscript has been published as part of the dissertation of $\mathrm{AB}$, "Effect of Foliage and Root Carbon Quantity, Quality, and Fluxes on Soil Organic Carbon Stabilization in Montane Aspen and Conifer Stands in Utah" (2017). All Graduate Theses and Dissertations. 6505. https://digitalcommons.usu.edu/etd/6505.

\section{SUPPLEMENTARY MATERIAL}

The Supplementary Material for this article can be found online at: https://www.frontiersin.org/articles/10.3389/ffgc.2020. 594473/full\#supplementary-material 


\section{REFERENCES}

Aiken, G. (2014). "Fluorescence and dissolved organic matter: a chemist's perspective," in Aquatic Organic Matter Fluorescence. Ed. P. G. Coble (Cambridge: Cambridge University Press), 35-74. doi: 10.1017/ CBO9781139045452.005

Augusto, L., De Schrijver, A., Vesterdal, L., Smolander, A., Prescott, C., and Ranger, J. (2014). Influences of evergreen gymnosperm and deciduous angiosperm tree species on the functioning of temperate and boreal forests. Biol. Rev. Camb. Philos. Soc. 90, 444-466. doi: 10.1111/brv.12119

Ayres, E., Steltzer, H., Berg, S., Wallenstein, M. D., Simmons, B. L., and Wall, D. H. (2009). Tree species traits influence soil physical, chemical, and biological properties in high elevation forests. PLoS One 4:e5964. doi: 10.1371/journal. pone.0005964

Bauhus, J., and Messier, C. (1999). Soil exploitation strategies of fine roots in different tree species of the southern boreal forest of eastern Canada. Can. J. For. Res. 29, 260-273. doi: 10.1139/cjfr-29-2-260

Beggs, K. M. H., and Summers, R. S. (2011). Character and chlorine reactivity of dissolved organic matter from a mountain pine beetle impacted watershed. Environ. Sci. Technol. 45, 5717-5724. doi: 10.1021/es1042436

Boča, A., and Van Miegroet, H. (2017). Can carbon fluxes explain differences in soil organic carbon storage under aspen and conifer forest overstories? Forests 8:118. doi: 10.3390/f8040118

Boča, A., Van Miegroet, H., and Gruselle, M.-C. (2014). Forest overstory effect on soil organic carbon storage: a meta-analysis. Soil Sci. Soc. Am. J. 78:S35 doi: 10.2136/sssaj2013.08.0332nafsc

Borken, W., and Matzner, E. (2009). Reappraisal of drying and wetting effects on $\mathrm{C}$ and $\mathrm{N}$ mineralization and fluxes in soils. Glob. Chang. Biol. 15, 808-824. doi: 10.1111/j.1365-2486.2008.01681.x

Cotrufo, M. F., Soong, J. L., Horton, A. J., Campbell, E. E., Haddix, M. L., Wall, D. H., et al. (2015). Formation of soil organic matter via biochemical and physical pathways of litter mass loss. Nat. Geosci. 8, 776-779. doi: 10.1038/ ngeo2520

Craig, M. E., Turner, B. L., Liang, C., Clay, K., Johnson, D. J., and Phillips, R. P. (2018). Tree mycorrhizal type predicts within-site variability in the storage and distribution of soil organic matter. Glob. Chang. 24, 3317-3330. doi: 10.1111/ gcb. 14132

Cuss, C. W., Shi, Y. X., McConnell, S. M., and Guéguen, C. (2014). Changes in the fluorescence composition of multiple DOM sources over $\mathrm{pH}$ gradients assessed by combining parallel factor analysis and self-organizing maps. J. Geophys. Res. Biogeosci. 119, 1850-1860. doi: 10.1002/2013JG002598

DeRose, R. J., and Long, J. N. (2007). Disturbance, structure, and composition: spruce beetle and engelmann spruce forests on the Markagunt Plateau. Utah. For. Ecol. Manage. 244, 16-23. doi: 10.1016/j.foreco.2007.03.065

Di Orio, A. P., Callas, R., and Schaefer, R. J. (2005). Forty-eight year decline and fragmentation of aspen (Populus tremuloides) in the South Warner Mountains of California. For. Ecol. Manage. 206, 307-313. doi: 10.1016/j.foreco.2004.11. 011

Dilling, J., and Kaiser, K. (2002). Estimation of the hydrophobic fraction of dissolved organic matter in water samples using UV photometry. Water Res 36, 5037-5044. doi: 10.1016/S0043-1354(02)00365-2

Fellman, J. B., Hood, E., and Spencer, R. G. M. (2010). Fluorescence spectroscopy opens new windows into dissolved organic matter dynamics in freshwater ecosystems: a review. Limnol. Oceanogr. 55, 2452-2462. doi: 10.4319/lo.2010. 55.6.2452

Finér, L., Messier, C., and De Grandpré, L. (1997). Fine-root dynamics in mixed boreal conifer - broad-leafed forest stands at different successional stages after fire. Can. J. For. Res. 27, 304-314. doi: 10.1139/x96-170

Fröberg, M., Berggren, D., Bergkvist, B., Bryant, C., and Knicker, H. (2003). Contributions of $\mathrm{Oi}$, Oe and Oa horizons to dissolved organic matter in forest floor leachates. Geoderma 113, 311-322. doi: 10.1016/S0016-7061(02)00367-1

Gabor, R. S., Baker, A., McKnight, D. M., and Miller, M. P. (2014a). "Fluorescence indices and their interpretation," in Aquatic Organic Matter Fluorescence, eds P. G. Coble, J. Lead, A. Baker, D. M. Reynolds, and R. G. Spencer (Cambridge: University Press), 303-338. doi: 10.1017/cbo9781139045452.015

Gabor, R. S., Eilers, K., McKnight, D. M., Fierer, N., and Anderson, S. P. (2014b). From the litter layer to the saprolite: chemical changes in water-soluble soil organic matter and their correlation to microbial community composition. Soil Biol. Biochem. 68, 166-176. doi: 10.1016/j.soilbio.2013.09.029

Giardina, C. P., Ryan, M. G., Hubbard, R. M., and Binkley, D. (2001). Tree species and soil textural controls on carbon and nitrogen mineralization rates. Soil Sci. Soc. Am. J. 65, 1272-1279. doi: 10.2136/sssaj2001.6541272x

Gueguen, C., Cuss, C. W., Cassels, C. J., and Carmack, E. C. (2014). Absorption and fluorescence of dissolved organic matter in the waters of the Canadian Artic Archiipelago, Baffin Bay, and the Labrador Sea. J. Geophys. Res. Ocean. 119, 2034-2047. doi: 10.1002/2013JC009173.Received

Hansson, K., Kleja, D. B., Kalbitz, K., and Larsson, H. (2010). Amounts of carbon mineralised and leached as DOC during decomposition of Norway spruce needles and fine roots. Soil Biol. Biochem. 42, 178-185. doi: 10.1016/j.soilbio. 2009.10.013

Hassink, J. (1997). The capacity of soils to preserve organic C and N by their association with clay and silt particles. Plant Soil 191, 77-87.

Heckman, K., Vazquez-Ortega, A., Gao, X., Chorover, J., and Rasmussen, C. (2011). Changes in water extractable organic matter during incubation of forest floor material in the presence of quartz, goethite and gibbsite surfaces. Geochim. Cosmochim. Acta 75, 4295-4309. doi: 10.1016/j.gca.2011.05.009

IPCC (2019). Climate Change and Land: an IPCC Special Report on Climate Change, Desertification, Land Degradation, Sustainable Land Management, Food Security, and Greenhouse Gas Fluxes in Terrestrial Ecosystems. Geneva: IPCC.

Jarvis, P., Rey, A., Petsikos, C., Wingate, L., Rayment, M., Pereira, J., et al. (2007). Drying and wetting of Mediterranean soils stimulates decomposition and carbon dioxide emission: the "Birch effect.". Tree Physiol. 27, 929-940. doi: 10.1093/treephys/27.7.929

Kaiser, K., and Guggenberger, G. (2000). The role of DOM sorption to mineral surfaces in the preservation of organic matter in soils. Org. Geochem. 31, 711-725. doi: 10.1016/S0146-6380(00)00046-2

Kalbitz, K., and Kaiser, K. (2008). Contribution of dissolved organic matter to carbon storage in forest mineral soils. J. Plant Nutr. Soil Sci. 171, 52-60. doi: 10.1002/jpln.200700043

Kalbitz, K., Schmerwitz, J., Schwesig, D., and Matzner, E. (2003). Biodegradation of soil-derived dissolved organic matter as related to its properties. Geoderma 113, 273-291. doi: 10.1016/S0016-7061(02)00365-8

Kalbitz, K., Schwesig, D., Rethemeyer, J., and Matzner, E. (2005). Stabilization of dissolved organic matter by sorption to the mineral soil. Soil Biol. Biochem. 37, 1319-1331. doi: 10.1016/j.soilbio.2004.11.028

Kiikkilä, O., Kitunen, V., Spetz, P., and Smolander, A. (2012). Characterization of dissolved organic matter in decomposing Norway spruce and silver birch litter. Eur. J. Soil Sci. 63, 476-486. doi: 10.1111/j.1365-2389.2012.01457.x

Kothawala, D. N., Moore, T. R., and Hendershot, W. H. (2008). Adsorption of dissolved organic carbon to mineral soils: a comparison of four isotherm approaches. Geoderma 148, 43-50. doi: 10.1016/j.geoderma.2008.09.004

Kramer, M. G., Sanderman, J., Chadwick, O. A., Chorover, J., and Vitousek, P. M. (2012). Long-term carbon storage through retention of dissolved aromatic acids by reactive particles in soil. Glob. Chang. Biol. 18, 2594-2605. doi: 10.1111/j. 1365-2486.2012.02681.x

Laganière, J., Boča, A., Van Miegroet, H., and Paré, D. (2017). A tree species effect on soil that is consistent across the species' range: the case of aspen and soil carbon in North America. Forests 8:113. doi: 10.3390/f8040113

Laganiére, J., Paré, D., Bergeron, Y., Chen, H. Y. H., Brassard, B. W., and Cavard, X. (2013). Stability of soil carbon stocks varies with forest composition in the canadian boreal biome. Ecosystems 16, 852-865. doi: 10.1007/s10021-0139658-z

LaMalfa, E. M., and Ryle, R. (2008). Differential snowpack accumulation and water dynamics in aspen and conifer communities: implications for water yield and ecosystem function. Ecosystems 11, 569-581. doi: 10.1007/s10021-008-9143-2

Lavallee, J. M., Conant, R. T., Paul, E. A., and Cotrufo, M. F. (2018). Incorporation of shoot versus root-derived $13 \mathrm{C}$ and $15 \mathrm{~N}$ into mineral-associated organic matter fractions: results of a soil slurry incubation with dual-labelled plant material. Biogeochemistry 137, 379-393. doi: 10.1007/s10533-018-0428-z

Lilienfein, J., Qualls, R. G., Uselman, S. M., and Bridgham, S. D. (2004). Adsorption of dissolved organic carbon and nitrogen in soils of a weathering chronosequence. Soil Sci. Soc. Am. J. 68, 292-305. doi: 10.2136/sssaj2004.2920

Lin, G., McCormack, M. L., Ma, C., and Guo, D. (2017). Similar below-ground carbon cycling dynamics but contrasting modes of nitrogen cycling between 
arbuscular mycorrhizal and ectomycorrhizal forests. New Phytol. 213, 14401451. doi: $10.1111 / \mathrm{nph} .14206$

Little, E. L. (1971). Conifers and Important Hardwoods, in: Atlas of United States Trees. Washington, DC: U.S. Department of Agriculture Miscellaneous Publication, 1146.

Manzoni, S., Taylor, P., Richter, A., Porporato, A., and Agren, G. I. (2012). Environmental and stoichiometric controls on microbial carbon-use efficiency in soils. New Phytol. 196, 79-91. doi: 10.1111/j.1469-8137.2012.04225.x

McKenney, D. W., Pedlar, J. H., Lawrence, K., Hutchinson, M. F., Kenney, D. W. M. C., and Campbell, K. (2007). Potential impacts of climate change on the distribution of north american trees. Bioscience 57, 939-948. doi: 10.1641/ b571106

McKnight, D. M., Boyer, E. W., Westerhoff, P. K., Doran, P. T., Kulbe, T., and Anderson, D. T. (2001). Spectroflourometric characterization of dissolved organic matter for indication of precursor organic material and aromaticity. Limnol. Oceanogr. 46, 38-48. doi: 10.4319/lo.2001.46.1.0038

McNab, W. H., and Avers, P. E. (1994). Ecological Subregions of the United States: Section Descriptions. Washington, DC: U.S. Department of Agriculture, Forest Service.

Michalzik, B., Kalbitz, K., Park, J., and Solinger, S. (2001). Fluxes and concentrations of dissolved organic carbon and nitrogen - a synthesis for temperate forests. Biogeochemistry 52, 173-205.

Miller, M. P., Simone, B. E., McKnight, D. M., Cory, R. M., Williams, M. W., and Boyer, E. W. (2010). New light on a dark subject: comment. Aquat. Sci. 72, 269-275. doi: 10.1007/s00027-010-0130-2

Moore, T. R., De Souza, W., and Koprivnjak, J.-F. (1992). Controls on the sorption of dissolved organic carbon by soils. Soil Sci. 154, 120-129.

Moore, T. R., Trofymow, J. A., Prescott, C. E., Fyles, J., and Titus, B. D. (2006). Patterns of carbon, nitrogen and phosphorus dynamics in decomposing foliar litter in Canadian forests. Ecosystems 9, 46-62. doi: 10.1007/s10021-0040026-x

Murphy, K. R., Hambly, A., Singh, S., Henderson, R. K., Baker, A., Stuetz, R., et al. (2011). Organic matter fluorescence in municipal water recycling schemes: toward a unified PARAFAC model. Environ. Sci. Technol. 45, 2909-2916. doi: 10.1021/es103015e

Murphy, K. R., Stedmon, C. A., Graeber, D., and Bro, R. (2013). Fluorescence spectroscopy and multi-way techniques. PARAFAC. Anal. Methods 5, 65576566. doi: 10.1039/c3ay41160e

Murphy, K. R., Stedmon, C. A., Wenig, P., and Bro, R. (2014). OpenFluoran online spectral library of auto-fluorescence by organic compounds in the environment. Anal. Methods 6, 658-661. doi: 10.1039/C3AY41935E

Olsen, H. R., and Van Miegroet, H. (2010). Factors affecting carbon dioxide release from forest and rangeland soils in northern utah. Soil Sci. Soc. Am. J. 74, 282-291. doi: 10.2136/sssaj2009.0095

Pan, Y., Birdsey, R., Fang, J., Houghton, R., Kauppi, P. E., Kurz, W., et al. (2011). A large and persistent carbon sink in the world's forests. Science 333, 988-993. doi: $10.1126 /$ science. 1201609

Potter, D. A. (1998). Forested Communities of the Upper Montane in the Centeral and Southern Sierra Nevada. General technical report PSW-169, Albany, NY: USDA Forest Service, Pacific Southwest Research Station.

Prescott, C. E., Zabek, L. M., Staley, C. L., and Kabzems, R. (2000). Decomposition of broadleaf and needle litter in forests of British Columbia: influences of litter type, forest type, and litter mixtures. Can. J. For. Res. 30, 1742-1750. doi: $10.1139 / \mathrm{x} 00-102$

Qualls, R. G. (2000). Comparison of the behavior of soluble organic and inorganic nutrients in forest soils. For. Ecol. Manage. 138, 29-50. doi: 10.1016/S03781127(00)00410-2

R Development Core Team (2015). R: A Language and Environment for Statistical Computing. Vienna: R Development Core Team.

Reich, P. B., Wright, I. J., Cavender-Bares, J., Craine, J. M., Oleksyn, J., Westoby, M., et al. (2003). The evolution of plant functional variation: traits, spectra, and strategies. Int. J. Plant Sci. 164, S143-S164. doi: 10.1086/374368

Rogers, P. (2002). Using forest health monitoring to assess aspen forest cover change in the southern Rockies ecoregion. For. Ecol. Manage. 155, 223-236. doi: 10.1016/S0378-1127(01)00560-6

Román Dobarco, M., Jacobson, A. R., and Van Miegroet, H. (2020). Chemical composition of soil organic carbon from mixed aspen- conifer forests characterized with fourier transform infrared spectroscopy. Eur. J. Soil Sci. Epub ahead of print doi: 10.1111/ejss.13065

Román Dobarco, M., and Van Miegroet, H. (2014). Soil Organic Carbon Storage and Stability in the Aspen-Conifer Ecotone in Montane Forests in Utah State. USA. Forests 5, 666-688. doi: 10.3390/f5040666

Six, J., Conant, R. T., Paul, E. A., and Paustian, K. (2002). Stabilization mechanisms of soil organic matter: implications for C-saturation of soils. Plant Soil 241, 155-176.

Sparks, D. L., Page, A. L., Helmke, P. A., and Loeppert, R. H. (eds) (1996). Methods of Soil Analysis Part 3-Chemical Methods SSSA Book Ser. 5.3. Wisconsin, WI: Soil Science Society of America.

Startsev, N., Lieffers, V. J., and Landhäusser, S. M. (2008). Effects of leaf litter on the growth of boreal feather mosses: implication for forest floor development. J. Veg. Sci. 19, 253-260. doi: 10.3170/2008-8-18367

Stedmon, C. A., Thomas, D. N., Granskog, M., Kaartokallio, H., Papdimitriou, S., and Kuosa, H. (2007). Characteristics of dissolved organic matter in baltic coastal sea ice: allochtonous or autochtonous origins? Environ. Sci Technol. 41, 7273-7279. doi: 10.1021/es071210f

Steele, S. J., Gower, S. T., Vogel, J. G., and Norman, J. M. (1997). Root mass, net primary production and turnover in aspen, jack pine and black spruce forests in Saskatchewan and Manitoba. Canada. Tree Physiol. 17, 577-587. doi: 10.1029/97JD02317

Stewart, C. E., Paustian, K., Conant, R. T., Plante, A. F., and Six, J. (2007). Soil carbon saturation: concept, evidence and evaluation. Biogeochemistry 86, 19-31. doi: 10.1007/s10533-007-9140-0

Strid, A., Lee, B. S., and Lajtha, K. (2016). Homogenization of detrital leachate in an old-growth coniferous forest, OR: DOC fluorescence signatures in soils undergoing long-term litter manipulations. Plant Soil 408, 133-148. doi: 10. 1007/s11104-016-2914-1

Sutton, R., and Sposito, G. (2005). Molecular structure in soil humic substances: the new view. Environ. Sci. Technol. 39, 9009-9015. doi: 10.1021/es050778q

Taylor, B. R., Parsons, W. F. J., and Parkinson, D. (1989). Decomposition of Populus tremuloides leaf litter accelerated by addition of Alnus crispa litter. Can. J. For. Res. 19, 674-679. doi: 10.1139/x89-104

Taylor, L. L., Leake, J. R., Quirk, J., Hardy, K., Banwart, S. A., and Beerling, D. J. (2009). Biological weathering and the long-term carbon cycle: integrating mycorrhizal evolution and function into the current paradigm. Geobiology 7 , 171-191. doi: 10.1111/j.1472-4669.2009.00194.x

Uselman, S. M., Qualls, R. G., and Lilienfein, J. (2007). Contribution of root vs . leaf litter to dissolved organic carbon leaching through soil. Soil Sci. Soc. Am. J. 71, 1555-1563. doi: 10.2136/sssaj2006.0386

Uselman, S. M., Qualls, R. G., and Lilienfein, J. (2012). Quality of soluble organic $\mathrm{C}, \mathrm{N}$, and P produced by different types and species of litter: root litter versus leaf litter. Soil Biol. Biochem. 54, 57-67. doi: 10.1016/j.soilbio.2012.03.021

Van Miegroet, H., Boettinger, J. L., Baker, M. A., Nielsen, J., Evans, D., and Stum, A. (2005). Soil carbon distribution and quality in a montane rangeland-forest mosaic in northern Utah. For. Ecol. Manage. 220, 284-299. doi: 10.1016/j. foreco.2005.08.017

Vandenbruwane, J., De Neve, S., Qualls, R. G., Sleutel, S., and Hofman, G. (2007). Comparison of different isotherm models for dissolved organic carbon (DOC) and nitrogen (DON) sorption to mineral soil. Geoderma 139, 144-153. doi: 10.1016/j.geoderma.2007.01.012

Vesterdal, L., Clarke, N., Sigurdsson, B. D., and Gundersen, P. (2013). Do tree species influence soil carbon stocks in temperate and boreal forests?. For. Ecol. Manage. 309, 4-18. doi: 10.1016/j.foreco.2013.01.017

Vogel, C., Mueller, C. W., Höschen, C., Buegger, F., Heister, K., Schulz, S., et al. (2014). Submicron structures provide preferential spots for carbon and nitrogen sequestration in soils. Nat. Commun. 5:2947. doi: 10.1038/ncomms 3947

Wadleigh, L., and Jenkins, M. J. (1996). Fire frequency and the vegetative mosaic of a spruce-fir forest in northern utah. Gt. Basin Nat. 56, 28-37. doi: 10.1017/ CBO9781107415324.004

Weishaar, J. L., Aiken, G. R., Bergamaschi, B. A., Fram, M. S., Fujii, R., and Mopper, K. (2003). Evaluation of specific ultraviolet absorbance as an indicator of the chemical composition and reactivity of dissolved organic carbon. Environ. Sci. Technol. 37, 4702-4708. doi: 10.1021/es0 30360x 
Wenig, P., and Odermatt, J. (2010). OpenChrom: a cross-platform open source software for the mass spectrometric analysis of chromatographic data. BMC Bioinformatics 11:405. doi: 10.1186/1471-2105-11-405

Wheeler, K. I., Levia, D. F., and Hudson, J. E. (2017). Tracking senescenceinduced patterns in leaf litter leachate using parallel factor analysis (PARAFAC) modeling and self-organizing maps. J. Geophys. Res. Biogeosci. 122, 2233-2250. doi: 10.1002/2016JG003677

Woldeselassie, M., Van Miegroet, H., Gruselle, M.-C., and Hambly, N. (2012). Storage and stability of soil organic carbon in aspen and conifer forest soils of northern utah. Soil Sci. Soc. Am. J. 76:2230. doi: 10.2136/sssaj2011.0364
Conflict of Interest: The authors declare that the research was conducted in the absence of any commercial or financial relationships that could be construed as a potential conflict of interest.

Copyright (C) 2020 Boča, Jacobson and Van Miegroet. This is an open-access article distributed under the terms of the Creative Commons Attribution License (CC BY). The use, distribution or reproduction in other forums is permitted, provided the original author(s) and the copyright owner(s) are credited and that the original publication in this journal is cited, in accordance with accepted academic practice. No use, distribution or reproduction is permitted which does not comply with these terms. 